\title{
ESTRATEGIAS NARRATIVAS Y MUSICALES EN EL WÉSTERN ESPAÑOL DE LOS AÑOS SESENTA: DOS FILMES DE RAMÓN TORRADO CON MÚSICA DE DANIEL MONTORIO ${ }^{1}$
}

\author{
NARRATIVE AND MUSICAL STRATEGIES IN THE SPANISH WESTERN \\ OF THE 1960s: TWO FILMS BY RAMÓN TORRADO WITH MUSIC BY \\ DANIEL MONTORIO
}

\section{Resumen}

En 1964, el compositor Daniel Montorio (1904-1982) escribe la música para dos wésterns dirigidos por Ramón Torrado (1905-1990): Relevo para un pistolero y Los cuatreros. Por entonces, los wésterns españoles - fueran o no coproducciones - se producían en serie, había una infraestructura industrial consolidada y unas narrativas influidas por el cine norteamericano. Torrado y Montorio eran profesionales veteranos y realizaron dos films de éxito, de línea clásica anterior al cambio de paradigmas visuales, sonoros y narrativos del spaguetti western que se impondría tras la Trilogía del Dólar de Leone y Morricone. Partiendo de los estudios sobre la presencia del tópico pastoral en la música de cine (N. Lerner, 2001; M. Beckerman y W. H. Rosar, 2009), los análisis semióticos de P. Tagg y B. Clarida de The Virginian (2003), las obras de K. Kalinak sobre la música del western americano (2007, 2012) y el estudio del funcionamiento mitopoético de la música en el cine de género (T. Scheurer, 2005), este artículo aborda el análisis de la música de estos filmes como práctica discursiva, desde una perspectiva semiótica. El objetivo es analizar las funciones de la música en las narrativas fílmicas, así como valorar la presencia de tópicos musicales consolidados en el western norteamericano (M. Whitmer, 2012 y 2018; R. J. Stilwell, 2016) en la música de Montorio, confirmando que tanto las canciones diegéticas como la música extradiegética fueron herramientas eficaces en la definición del "cine de género" popular y comercial en la España de los años sesenta.

Palabras clave

Música de cine español, Western, Daniel Montorio (1904-1982).

\footnotetext{
${ }^{1}$ Este artículo se ha realizado en el marco del Proyecto Música y medios audiovisuales en España: creación, mediación y negociación de significados (MusMAE) (Referencia: MCI-20PID2019-106479GB-I00), financiado por la Agencia Estatal de Investigación (AEI), 10.13039/501100011033.
}

Celsa Alonso González

Universidad de Oviedo celsa@uniovi.es

ORCID ID: 0000-0002-7811-8506

\section{Abstract}

In 1964, the composer Daniel Montorio (1904-1982) wrote the music for two westerns directed by Ramón Torrado (1905-1990): Relevo para un pistolero and Los cuatreros. At that time, Spanish westerns - whether or not they were co-productions - were massproduced, the film industry had a consolidated infrastructure, and narratives were influenced by North American cinema. Torrado and Montorio were veteran professionals and they made two successful films, following the classic patterns of the genre, before the innovations of visuals, sound and narrative in the spaghetti western that would prevail after the Leone and Morricone Dollar Trilogy. Following studies on the presence of pastoral topic in film music $(\mathrm{N}$. Lerner, 2001; M. Beckerman and W. H. Rosar, 2009), the semiotic analysis of P. Tagg and B. Clarida for The Virginian (2003), the works of K. Kalinak on the music of the American western $(2007,2012)$ and the study of mythopoetic of music in genre cinema (T. Scheurer, 2005), this article analyzes the music of these films as a discursive practice, from a semiotic perspective. The objective is to analyze the functions of music in filmic narratives, and to assess the presence of musical topics conosolidated in the North American western (M. Whitmer, 2012 and 2018; R. J. Stilwell, 2016) in Montorio's film music, confirming that both diegetic songs and extradiegetic music were effective tools in the definition of Spanish popular and commercial "genre cinema" during the sixties.

\section{Key words}

Spanish Film Music, Spaguetti Western, Daniel Montorio (1904-1982). 
El wéstern español de los años sesenta es un género cinematográfico poco investigado en el mundo académico, quizá porque fue un cine comercial producido en serie y la mayoría de las investigaciones se han centrado en el cine "de autor" (en particular el llamado nuevo cine español) o, más recientemente, en un cine popular basado en la tradición de la comedia y el musical. ${ }^{2}$ La década 1960-70 estuvo marcada por el nombramiento, en 1962, de José M ${ }^{\mathrm{a}}$ García Escudero como Director General de Cinematografía y Teatro, a quien se considera responsable de gestionar la estrategia del régimen franquista para re-construir la imagen del país a través del cine, y de hacer la revolución cinematográfica "desde arriba". ${ }^{3}$ En el ámbito del cine comercial, triunfó la denominada "comedia costumbrista del desarrollismo" y la amable "comedia blanca" con temas recurrentes como el turismo, la emigración o el enfrentamiento campo/ciudad. ${ }^{4}$ Asimismo, continuó el éxito del cine musical — desde las películas de Marisol al cine pop de influencia británica- y se consolidaron nuevos géneros, entre ellos el spaghetti-western o el cine de horror. Tras la aprobación, en 1964, de las Nuevas Normas para el Desarrollo de la Cinematografía Nacional, finalizó el antiguo sistema de clasificación por categorías, y se modificó la política de subvenciones estatales. Desde entonces, los beneficios estatales -al margen de las cintas de "interés especial" — ya no dependieron de las evaluaciones de calidad de las películas, sino de las posibilidades comerciales del film, lo que favoreció al cine comercial, al wéstern español y a las coproducciones. ${ }^{5}$

\footnotetext{
2 Entre las excepciones destaca Pedro Gutiérrez Recacha, quien defendió su tesis doctoral sobre el wéstern español en 2006 en la Universidad Autónoma de Madrid: Origen y consolidación del wéstern como subgénero filmico en la cinematografia española (1954-1965), dirigida por Valeria Camporesi y Luis Fernández Colorado, origen de una monografía publicada en 2010.

3 Santos Zunzunegui, Los felices sesenta: aventuras y desventuras del cine español (1959-1971) (Barcelona: Paidos, 2005), p. 19.

4 Miguel Ángel Huerta Floriano, Los géneros cinematográficos. Usos en el cine español (1994-1999) (Salamanca: Publicaciones Universidad Pontificia, 2005), pp. 139-140.

5 Pedro Gutiérrez Recacha, Spanish Western: el cine del Oeste como subgénero español (1954-1965) (Madrid: Ediciones de la Filmoteca, 2010), p. 224. Gutiérrez Recacha ofrece unos exhaustivos datos de estrenos, espectadores y carteleras.
}

\section{DEL WÉSTERN ESPAÑOL AL SPAGUETTI- WESTERN}

Entre 1960 y 1970, en España se rodaron numerosos wésterns, muchos de ellos coproducidos con Italia y la República Federal de Alemania, otros con EE.UU y Reino Unido, que alcanzaron una notable popularidad: entre 1962 y 1969 se produjeron nada menos que 158 wésterns - sobre todo tras el impacto de Por un puñado de dólares (Sergio Leone, 1964)—, es decir casi la tercera parte de la producción fílmica española. ${ }^{6}$ Se trata de una situación excepcional en la industria del cine nacional, con una producción masiva en serie a un coste mínimo, importantes inversiones extranjeras y resultados comerciales muy notables.

No obstante, en España el wéstern no comienza en los primeros años de la década de 1960-70 bajo la influencia del cine norteamericano, pues había una tradición de wéstern español anterior marcado por el personaje literario de El Coyote. En 1954 Joaquín Romero Marchent (1921-2012) dirigió el díptico El Coyote y La justicia del Coyote, con música de Odón Alonso, que supuso toda una novedad en un momento en que en Italia aún no se filmaban wésterns. ${ }^{8}$ Romero Marchent se inspiró en la buena acogida que el wéstern de enmascarados había tenido en México, e intentó capitalizar en España la popularidad de las novelas de José Mallorquí (19131972), particularmente la serie de El Coyote (1944-1953), cuyo eje argumental era la aportación española en la conquista del Oeste, donde se mostraba un Far West españolizado con una visión negativa de los yanquis. ${ }^{9}$ Tampoco las coproducciones entre España e Italia comenzaron en

\footnotetext{
${ }^{6}$ Huerta Floriano, Los géneros cinematográficos, p. 138.

7 Gutiérrez Recacha, Spanish Western, p. 409. Las cifras aportadas por el autor son relevantes: en 1963, se produjeron 13 wésterns (de un total de 113 producciones ese año), y en 1964 la cifra ascendió a 28 (de un total de 130), lo que arroja un resultado de un 21,5\% frente al 9\% del año anterior. En 1965 se produjeron nada menos que 45 wésterns (de un total de 151 filmes) lo que supone casi un $30 \%$ de la producción nacional.

${ }^{8}$ De hecho, estos filmes inauguran la filmografía elaborada por Kevin Grant en Any gun can play. The essential guide to Euro-Westerns (Surrey: Fab Press, 2011). El primer wéstern italiano fue La sceriffa (El sheriff) de Roberto Bianchi Montero, de 1959.

9 Carlos Aguilar, "Entre zorros y coyotes: la extraña raíz del wéstern hispano-italiano de los años 60", Los límites de la frontera: la coproducción en el cine español, Cuadernos de la Academia, 5 (mayo, 1999), pp. 29-41, 34.
} 
los años sesenta sino en la década anterior, momento en el que ocuparon casi el $61 \%$ de las coproducciones que se hacían en nuestro país. ${ }^{10}$

Tras las normas de 1964, las coproducciones se incrementaron, y con ello los wésterns. En 1964, 1 de cada 5 películas rodadas en España fue un wéstern, mientras en 1965 la proporción se eleva a 1 de cada 3. ${ }^{11}$ Los productores más destacados fueron Eduardo Manzanos, José Gutiérrez Maesso y el propio Joaquín Romero Marchent. La mayoría de las bandas sonoras fueron escritas por compositores italianos como Riz Ortolani, Francesco de Masi, Carlo Rustichelli, Piero Piccioni, Stelvio Cipriani y Ennio Morricone (antes de la Trilogía del Dolar), debido a dos razones que apunta Joan Padrol: por su sólida profesionalidad y por motivos económicos, dado que muchos directores y productores "saqueaban" los catálogos de discos de Ediciones Musicales CAM para recortar presupuesto. ${ }^{12}$ Padrol sólo señala dos excepciones: Antón García Abril todo un hito fue Tierra brutal (1962) con una banda sonora al estilo de Elmer Bernstein-y Antonio Pérez Olea, formado en Italia con Angelo Francesco Lavagnino. ${ }^{13}$

El bienio 1964-65 es fundamental en tanto fin de una etapa, ya que, a partir del éxito de la Trilogía del Dólar de Leone y Morricone, el papel de los profesionales españoles en el género se redujo drásticamente en favor de un wéstern que bien puede calificarse de italiano: de hecho, el término spaguetti-western se afianzó en la prensa especializada española a partir de $1965-66 .{ }^{14}$ Las cifras hablan por sí solas: entre 1963 y 1969 se produjeron más de 300 wésterns en Italia. ${ }^{15}$ El término spaguettiwestern no fue del agrado de muchos cineastas italianos, que consideraban que tenía connotaciones negativas por su encasillamiento como género comercial producido en

${ }^{10}$ Carlos Heredero, Las huellas del tiempo. Cine español 1951-1961 (Valencia: Filmoteca de la Generalitat Valenciana, 1993), p. 266.

11 Gutiérrez Recacha, Spanish Western, p. 211-213.

12 Joan Padrol, "La música en las coproducciones con Italia", Los límites de la frontera, pp. 213-219.

13 Antonio Pérez Olea hizo carrera en Italia con wésterns como Noche de verano/Il peccato (Jorge Grau, 1962), Joaquín Murrieta (George Sherman, 1964), y Los cien caballeros/I cento cavalieri/Herren Partie (Vittorio Cottafavi, 1965) cuya música fue grabada en disco para la CAM; véase Padrol, "La música en las coproducciones con Italia", p. 217.

${ }^{14}$ Gutiérrez Recacha, Spanish Western, p. 367.

15 Christopher Frayling, Spaguetti-Westerns: cowboys and Europeans from Karl May to Sergio Leone (London: I. B. Tauris, 2006), p. 68. serie, pero lo cierto es que terminaría convirtiéndose en un significante genérico definido, en gran medida, por la idiosincrasia del lenguaje musical innovador de Ennio Morricone. ${ }^{16}$ Así, tras la irrupción del tándem LeoneMorricone, se modificaron los paradigmas del wéstern en todo el mundo, se alteró la perspectiva del Oeste y se deconstruyeron algunos códigos sólidamente implantados por el wéstern hollywoodiense (sobre todo la dicotomía héroe/villano), con un aumento considerable de la violencia y donde la música es casi un personaje más. ${ }^{17}$

Por ello, Relevo para un pistolero y Los cuatreros, dirigidas por Ramón Torrado con música de Daniel Montorio, ubicadas en el bienio 1964-65, no son spaguettiwestern en sentido estricto, sino que encajan en los esquemas de un wéstern europeo influido por las narrativas visuales y sonoras del cine americano. Estas películas no mostraban la visión españolizada del Far West del cine de Romero Marchent de la década anterior, pues desde 1961 se había impuesto un modelo narrativo caracterizado por la imitación del canon norteamericano - sobre todo la producción genérica de serie B de Hollywood-, inaugurado con Tierra brutal (I fuorilegge della valle solitaria) de Michael Carreras, rodada en 1961 y estrenada en 1962, una coproducción hispano-norteamericana de ambiente mexicano con música de García Abril que contó con la participación de la cantante Paquita Rico.

Como ya apuntamos, en 1964 se estrenaron en España nada menos que 28 wésterns —entre ellos Antes llega la muerte (I Sette del Texas) de Romero Marchent (música de Riz Ortolani) - , de los cuales sólo 5 alcanzaron los 21 días en las carteleras. Sin embargo, en 1965 Los cuatreros estuvo en cartelera más de tres semanas en algunos cines, fue la única producción española en alcanzar semejantes cifras, y superó nada menos que a Por un puñado de dólares (coproducción italo-hispano-alemana). ${ }^{18}$ Relevo para un pistolero y Los cuatreros fueron producidas por Atlantida Films

16 Robynn J. Stilwell, "The Western", en The Cambridge companion to film music, ed. Marveyn Cooke y Fionna Ford (Cambridge: Camdridge University Press, 2016), pp. 216-230, 216.

${ }^{17}$ Charles Leinberger, "The Dollars trilogy. 'There are two kinds of western heroes, my friend!'”, en Music in the Western. Notes from the frontier, ed. Kathryn Kalinak (New York: Rouledge, 2012), pp. 131-147, 134.

18 Gutiérrez Recacha, Spanish Western, p. 234. En 1965, Los cuatreros se estrenó en París con los títulos de crédito en inglés (Alone with a gun directed by Ray Torrad), lo que generó un pequeño escándalo que hizo intervenir a la Dirección General de Cinematografía. 
Cooperativa Cinematográfica y acogidas al crédito sindical. Hay que destacar que no fueron coproducciones, pero contaron con la participación de actores norteamericanos. El productor ejecutivo de Los cuatreros fue Arturo González, con amplia experiencia en Suevia Films, al igual que el director Ramón Torrado. Torrado acudió al veterano Daniel Montorio para la composición de la música, y el compositor aragonés diseñó unas partituras alejadas del mundo sonoro del spaguetti-western..$^{19}$ Sin llegar a la opulencia sinfónica de Tierra brutal y sin el conocimiento del medio que tenía Pérez Olea, la música de Montorio en estos filmes acusa la influencia del cine clásico de Hoollywood.

\section{RAMÓN TORRADO Y DANIEL MONTORIO: UNA COLABORACIÓN FRUCTÍFERA}

Ramón Torrado (1905-1990) comenzó a hacer cine después de la guerra civil y trabajó para la productora Suevia Films. Su mayor éxito fue Botón de ancla (1947), que mereció el segundo premio del Sindicato del Espectáculo y la categoría de Interés Nacional. ${ }^{20}$ Torrado hizo muchas películas de éxito popular: melodramas regionales, comedias blancas, musicales folklóricos y algunos filmes protagonizados por Lola Flores. Por su parte, Daniel Montorio (1904-1982), el compositor más prolífico del cine repúblicano, tras la guerra civil concentró su actividad en el teatro musical: entre 1939 y 1949, solo escribió música para 3 largometrajes y un documental dirigidos por Eduardo García Maroto, con quien ya había trabajado asiduamente en los años treinta. ${ }^{21}$ Uno de los largometrajes fue Oro vil (1941), considerado el primer wéstern español, obra bastante excepcional en aquel momento, hoy perdida y que fue un fracaso comercial. ${ }^{22}$

19 Para la comprensión del paradigma sonoro de Leone/Morricone, véase Sergio Miceli, "Leone, Morricone and the Italian way to revisionist Westerns", en The Cambridge companion to film music, ed. Marveyn Cooke y Fionna Ford (Cambridge: Camdridge University Press, 2016), pp. 265-294.

20 José Luis Castro de Paz, "Ramón Torrado, un asalariado del cine bajo el régimen de Franco", Actas del IV Congreso de la AEHC (Madrid: Editorial Complutense, 1993), pp. 289-298.

${ }^{21}$ La colaboración entre Montorio y García Maroto fue calificada por Manuel Rotellar como "una de las más fructíferas del cine español” en Aragón en el CINE (IV) (Zaragoza: Ayuntamiento de Zaragoza, 1973), p. 58. Véase también Celsa Alonso, "Daniel Montorio y Eduardo G. Maroto: Los cuatro robinsones (1939), del juguete astracanesco al cine musical", Revista de Musicología, 41/1 (2018), pp. 199-233.

${ }^{22}$ Rodada en los estudios de CEA y los exteriores en la Sierra
En los años cincuenta, Montorio continuó dedicado al teatro musical, con más de 40 títulos, escribió música para espectáculos pseudofolklóricos y abundantes canciones para un total de 14 largometrajes (comedias musicales y melodramas), protagonizados por Marujita Díaz, Lola Flores o Antonio Molina, entre otros:23 lograron especial notoriedad las canciones de Antonio Molina en Esa voz es una mina (Luis Lucía, 1955, con música incidental de José Ruiz de Azagra). Por entonces Torrado tenía algunos problemas con Suevia, de modo que se acercó a otras productoras que trabajaban para la distribuidora Cifesa, dedicándose al musical folklórico: ${ }^{24} \mathrm{es}$ el caso de la productora de Benito Perojo, con la que rodó Suspiros de Triana (1955), protagonizada por Paquita Rico y Angelillo, que supuso el primer encuentro entre Montorio y Torrado en el cine, pues Montorio escribió algunas canciones para el film.

Torrado regresó a Suevia Films y rodó cuatro películas más, entre 1956 y 1958. Mientras tanto, Montorio compuso las canciones y música incidental para tres películas protagonizadas por Antonio Molina, dirigidas por Gonzalo Delgrás: La hija de Juan Simón (1957), El Cristo de los Faroles (1958) y Café de Chinitas (1960). En 1961, Torrado fundó la cooperativa Copercines con el compositor Manuel Parada, el productor Eduardo Manzanos y Ricardo Torres, en cuyo seno dirigió Fray Escoba (1961) — uno de los grandes éxitos de su carrera-, Cristo Negro (1962) y Bienvenido, padre Murray (1963), todas ellas con banda sonora de Manuel Parada. Tras la experiencia en Copercines, en apenas un año Torrado dirigió 3 wésterns con la Cooperativa Cinematográfica Atlantida: Relevo para un pistolero (rodada en 1963, estrenada en 1964), Los cuatreros (rodada en 1964, estrenada en 1965) y La carga de la Policía Montada (1964, con música de Daniel White). El buen entendimiento de Torrado y Mon-

de Gredos, con producción de CEA y decorados del reputado Sigfrido Burmann, Oro vil fue distribuida por Hispania Tobis que la presentó como "la primera película de caballistas hecha en España" (Programa de mano. Barcelona: I. G. Vilador, ca. 1942). Filmoteca Nacional (C24-F12-D1.1). Montorio escribió para la película una canción con cantables de Maroto (Pensando en el amor). Un ejemplar del guion y parte de la música incidental se conservan en el Legado de Montorio en el Centro de Documentación y Archivo (CEDOA) de la SGAE (fondos inventariados, pero sin catalogar).

${ }^{23}$ Véase Javier Barreiro, Maestro Montorio. Medio siglo de música popular española (LCD Prames, 2004).

${ }^{24}$ Véase José Luis Castro de Paz y Jaime Pena Pérez, Ramón Torrado. Cine de consumo no franquismo (A Coruña: Centro Galego de Artes da Imaxe, 1993). 
torio les llevó a colaborar en varias comedias musicales protagonizadas por Manolo Escobar con la productora de Arturo González, de gran éxito popular: Mi canción es para ti (1965), Un beso en el puerto (1966) y El padre Manolo (1966). ${ }^{25}$ Con esta trilogía se ponía un excelente broche final a la colaboración entre director y compositor, en el ocaso de sus carreras cinematográficas.

\section{DOS WÉSTERNS ESPAÑOLES DE LÍNEA CLÁSICA}

Los wésterns de Ramón Torrado son películas de género rodadas en Cinemascope, protagonizadas por actores norteamericanos junto a secundarios españoles, exteriores filmados en España, ambas con fotografía de Ricardo Torres, otro veterano del cine español. Los filmes obedecen a los esquemas argumentales del wéstern americano que no demandaba mucha originalidad: mecanismos narrativos simples, cuadros de situación muy claros (duelo, venganza, emboscadas nocturnas, viajes) y una iconografía estable (carretas, saloon, pistolero, soldados, ganado, baile, desfiladeros, etc). Núñez Marqués califica a las dos películas de Torrado como "modestas aportaciones" al género anterior a Por un puñado de dólares. ${ }^{26}$

Relevo para un pistolero, con argumento y guion de Luis Gaspar y Antonio Giménez Escribano - colaboración de Torrado - y decorados de Augusto Lega, fue coprotagonizada por Alex Nicols (Relámpago) y Luis Dávila (Edwin Jackson). ${ }^{27}$ La película se rodó en blanco y negro - algo poco frecuente en aquel momento - , lo que le confiere cierta elegancia. ${ }^{28}$ Daniel Montorio escribió toda la música: canciones y música incidental original. ${ }^{29}$

\footnotetext{
${ }^{25}$ Para estas películas, Montorio escribió algunas canciones originales y la música incidental, y se añadieron otros temas del repertorio de Manolo Escobar grabadas por la discográfica Belter.

${ }^{26}$ Anselmo Núñez Marqués, Wéstern a la europea .... Un plato que se sirve frío (Madrid: Entrelíneas Editores, 2006), p. 81.

${ }^{27}$ Alex Nicol había trabajado como doble de Gary Cooper, y realizado varias películas norteamericanas (entre ellas El hombre de Laramie de Anthony Mann, 1955, y La hora de las pistolas de Jaques Tourneur, 1956) antes de protagonizar varios wésterns españoles, como Brandy (Cavalca e uccidi) de José Luis Borau (1963) y Los pistoleros de Casa Grande (Gunfighters of Casa Grande) de Roy Rowland (1963).

$28<\mathrm{http}$ ://800spaghettiwesterns.blogspot.com/2008/02/relevo-para-un-pistolero.html $>$ [consulta: 30/10/2020].

${ }^{29}$ En el Legado Montorio de la SGAE/CEDOA se conserva la música incidental original para orquesta (manuscritos fir-
}

El film narra la experiencia vital en el Oeste de un joven procedente de Boston, dinámico y con iniciativa, un tanto petimetre: Edwin Jackson. Edwin llega al pueblecillo de Blacktown con la intención de fundar un próspero negocio y pide consejo al expistolero Relámpago, antiguo amigo de su padre. Con la promesa de que no se dejará cautivar por la violencia de aquella tierra, Jackson abre una tienda de telas: Jackson Store. Para ello, pide dinero al dueño del Saloon Paradise y conoce a Ann, cantante del local. El negocio va bien, Edwin se asocia con el mexicano Raúl e inauguran otra tienda para los mexicanos atendida por la sobrina de Raúl: Carmen. Pero pronto empiezan los problemas con la banda de Jack Dylon, que tiene atemorizado al pueblo. Edwin se enfrenta a la banda, pero termina siendo víctima de la violencia del Oeste (mata a Dylon), de la corrupción moral y la impunidad del poder. El alcohol y su obsesión por Carmen le precipitan a un camino sin retorno, y paga con la muerte, en un duelo final con Relámpago, su debilidad de carácter.

Es muy interesante la evolución del personaje de Edwin Jackson, desde la ingenuidad, ilusión y sentido de la justicia, a la oscuridad, inmoralidad y vileza, algo que la música contribuye a narrar, como veremos. En el film están presentes varios elementos míticos del wéstern, como la redención del héroe (Relámpago), el problema racial (la entrada al Saloon y a las tiendas del pueblo está vedada a los mexicanos) y el contraste entre dualidades maniqueas: lo individual frente a la comunidad, la honestidad frente a la corrupción, el Oeste frente al Este, el progreso y la industriosidad frente al vicio (juego, alcohol, mujeres...). No obstante, en este mundo dual y hay varias grietas: el pistolero redimido no es tan protagonista como Edwin, el anti-héroe, cuya intención inicial era progresar con un negocio honrado y acabar con la discriminación de los mexicanos (aunque su motivación fuera puramente pecuniaria). Ann cataliza el enfrentamiento con Dylon pero, aunque mantiene una relación íntima con Edwin, intenta frenar la espiral de violencia y autodestrucción del joven alcoholizado y obsesionado por Carmen, a quien Edwin intenta violar y termina asesinando. Por ello, la historia de Relevo resulta mucho más interesante, escabrosa y real que Los cuatreros, como veremos, y tiene

mados con fecha del 27 de junio de 1964), una reducción para piano y textos mecanografiados de algunas canciones (Caja 2 y Caja 39. Material inventariado sin catalogar). Estas partituras manuscritas han sido las fuentes utilizadas para los análisis musicales y para la elaboración de los Ejemplos 1, 3 y 4 incluidos en este artículo. 
algo de tono elegíaco y crepuscular: en este sentido, acusa la influencia de algunos wésterns americanos de finales de los años cincuenta, que presentaban "cierto desencanto existencial" ${ }^{30} \mathrm{y}$, al mismo tiempo, parece adelantarse a su tiempo, con algunos hallazgos argumentales desarrollados en spaguetti-western posteriores como El día de la ira (1967) de Tonino Valeri. ${ }^{31}$

Por su parte, Los cuatreros se rodó en Cinemascope y Eastmancolor. Repitió Augusto Lega en los decorados, con argumento de Gregorio Almendros, guion de Almendros, Antonio Giménez Escribano, Fernando Butragueño y Ramón Torrado. El film fue protagonizado por Edmund Purdom y Frank Latimore en los papeles principales (Jim y Lad respectivamente) y, como en el caso anterior, la música incidental y canciones fueron escritas por Montorio. ${ }^{32}$ Rodada en 1964, la película se estrenó en Madrid y en París en 1965 y en Barcelona en 1966. El film cuenta la historia de los Thompson, propietarios de un rancho texano próximo a la frontera con México. Las autoridades descubren que el ganado del rancho atraviesa ilegalmente la frontera, pues una banda de cuatreros les roba las reses. Thompson no sospecha que su sobrino (Lad) dirige la banda para ganar dinero, ya que es un adicto al juego y está endeudado. Lad pretende casarse con su prima Mary para heredar el rancho, matrimonio que aprueba el cabeza de familia. Un día aparece un forastero (Jim) que salva a Thompson de intento de secuestro, se gana su confianza y es contratado como capataz. Jim y Mary comienzan a intimar, y Lad tiende una emboscada y acusa a Jim de un asesinato. Jim consigue huir de la cárcel, con la ayuda de la cantante del Saloon y los soldados federales, junto a un mexicano que le introduce en la banda de cuatreros. Jim es descubierto y en la huida logra deshacerse de toda la banda, aunque simula su muerte. Thompson enferma y muere, y Lad presiona a Mary para casarse cuanto antes. Al pueblo llega un cura que dice ser hermano gemelo de Jim y que desenmascara a Lad. Entonces se descubre su verdadera identidad: Jim es un teniente del ejército ame-

${ }^{30}$ Núñez Marqués, Wéstern a la europea, p. 34.

31 Gutiérrez Recacha, Spanish Western, p. 525.

32 En el Legado Montorio de la SGAE/CEDOA se conserva la música incidental manuscrita para orquesta (incompleta). Hay también un manuscrito con la reducción para piano, dos guiones manuscritos (con los apuntes de las entradas de la música por bloques, minutaje y breve descripción de la situación argumental). Todos los materiales están en la Caja 28, sin catalogar. Como en el caso de Relevo para un pistolero, los análisis musicales y los Ejemplos 2, 5, 6 y 7 se han realizado a partir de estos materiales. ricano encargado de destapar a la banda de cuatreros. Resuelto el misterio, la pareja decide casarse.

Los mecanismos narrativos de la película son mucho más sencillos que en Relevo, con un triángulo sentimental y un héroe impecable sin borroso pasado, y no hay lugar para profundizar en la psicología de los personajes. Gutiérrez Recacha señala esta película como un ejemplo paradigmático de simpleza argumental, habitual en las producciones en serie, con algunos diálogos de la pareja protagonista de notoria superficialidad. ${ }^{33}$ Otros críticos destacan la participación de Álvaro de Luna y Fernando Sancho como secundarios, califican la película como "muy correcta", de línea clásica, con excelente fotografía y buenos exteriores, aunque con una historia endeble, un actor protagonista al que falta empaque, y una "escena ridícula de una canción en un salón" en referencia a un número metateatral, que comentaré. ${ }^{34}$

\section{MÚSICAS PARA UN WÉSTERN ESPAÑOL: INFLUENCIAS, ESTRATEGIAS DISCURSIVAS Y CÓDIGOS COMPARTIDOS}

En 1992, Kathreen Kalinak señalaba una serie de convenciones presentes en las bandas sonoras del wéstern americano desde los filmes icónicos de John Ford: medio sinfónico, idioma clásico-romántico, música para mantener la unidad estructural y la coherencia de los mitos del género, para ilustrar el contenido narrativo - tanto implícito (emociones, estados de ánimo) como explícito (acción dramática)—, alto grado de sincronización entre música y acción narrativa, y protagonismo del diálogo sobre otros elementos de la banda sonora. ${ }^{35}$ Kalinak distingue dos corrientes musicales en el género: los wéstern de serie B de los años treinta explotaron la música country asociada al cowboy — así surgieron los llamados singing cowboy film - , mientras los wéstern producidos en los grandes estudios, sobre todo a partir de 1939, se decantaron por unas bandas sonoras inspiradas en la música de Roy Harris, Virgil Thomson o Aaron Copland, cuya estética se ubica en la búsqueda de un sonido "americano" capaz de establecer eficaces conexiones con la idea del Oeste, sus arquetipos geográficos (el llamado Wide Open

\footnotetext{
33 Gutiérrez Recacha, Spanish Western, p. 255.

$34<$ http://800spaghettiwesterns.blogspot.com/2008/02/loscuatreros.html $>$ [consulta: 30/10/2020].

${ }^{35}$ Kathryn Kalinak, Settling the score. Music and the classical Hollywood film (Madison, WI: University of Wisconsin Press, 1992), p. 79.
} 
Space) y míticos (el cowboy y el colono) ${ }^{36}$ El éxito de las cowboy songs, ligado al fortalecimiento de la industria musical, convirtió al singing cowboy en un potente agente sinérgico gracias al cual se establecieron estrechas relaciones entre disco, radio, edición musical, variedades y cine. ${ }^{37}$ Otras fuentes para las bandas sonoras del wéstern clásico fueron las músicas de los Wild West Shows y el melodrama del siglo XIX, como se comprueba en las colecciones de Erno Rapée y John Stepan Zamecnik destinadas a los músicos del cine mudo (particularmente las entradas denominadas Galloping, Hurry y Struggle). ${ }^{38}$

Con estos precedentes, en el wéstern americano de los años cuarenta y cincuenta predominaba la música sinfónica de naturaleza épica y narrativa, uso de leitmotiv, tópicos pastorales, música folk y canciones populares. Las canciones tenían un doble objetivo: articular una idea de "autenticidad americana" — con independencia de su origen-, realizar una importante función narrativa en la caracterización de algunos personajes y soportar parte de la carga ideológica del film. ${ }^{39}$ Por otro lado, la canción generaba "domesticidad" y simbolizaba la tensión narrativa entre el individualismo del hombre de frontera y las nociones de familia y comunidad. ${ }^{40}$ La combinación de lo sublime, lo pastoral (en tanto visión idílica del mundo rural) y la violencia es consustancial al wéstern, y el tópico pastoral (ligado tanto a los colonos y los pueblos de frontera como a los paisajes del Far West) aparece de forma reiterada en las bandas sonoras de naturaleza sin-

${ }^{36}$ Kathryn Kalinak, "Introduction", en Music in the Western. Notes from the frontier, ed. Kathryn Kalinak (New York, Rouledge, 2012), p. 3.

37 Véase Peter Stanfield, Horse Opera. The strange history of the 1930s singing cowboy (Chicago: University of Illinois Press, 2002). El autor analiza los wéstern de serie B producidos en estudios modestos e independientes de la maquinaria hollywoodiense en los años treinta, destinados a los pequeños cines de la América rural, que hicieron de mediadores entre la nostalgia del pasado y el presente, lo rual y lo urbano, la tradición y la modernidad, el trabajo y el capital en el marco del New Deal norteamericano.

${ }^{38}$ Mariana Whitmer, "Melodramatic music in the Western", Journal of Film Music, 5/1-2 (2012), pp. 109-119, 110. Véase también "The commodification of the Western soundscape", en Re-locating the sounds of the Western, ed. Mariana Whitmer y Kendra Preston Leonard (New York: Routledge, 2019).

39 Kathryn Kalinak, How the West was sung. Music in the Westerns of John Ford (Berkeley, CA: University of California Press, 2007), p. 2.

${ }^{40}$ Stilwell, "The Western", p. 220. fónica, en una especie de versión instrumental del singing cowboy como arquetipo cultural que se consolida durante la Gran Depresión. ${ }^{41}$ Particularmente relevante fue la influencia de Aaron Copland en las bandas sonoras de Dimitri Tiomkin, Hugo Friedhofer, Emil Newman, Jerome Moross y el propio Elmer Bernstein, sobre todo en lo concerniente al tópico pastoral y su evocación de las impactantes llanuras del Oeste. ${ }^{42}$

Desde una metodología basada en el análisis semiótico, Philip Tagg señala que los parámetros musicales que definen al wéstern son, en primer término, sinécdoques de lugar y anáfonas cinéticas (de manera especial las equinas, para las galopadas de los caballos). ${ }^{43}$ Tagg también identifica varios musemas para caracterizar a los cowboys (ritmos con puntillo y de ragtime, modos menores), a los indios - en ambos casos son habituales las escalas pentatónicas - y a la pradera (a través de lo que denomina "big country modalism" que termina convirtiéndose en un in-

${ }^{41}$ Michael Beckerman y William H. Rosar, "The idyllic sublime: a dialog on the pastoral style in Westerns", The Journal of Film Music, 2/ 2-4 (Winter 2009), pp. 251-262, 256. Robynn J. Stilwell, "The Western", p. 224, se refiere al tropo musical del Manifest Destiny vinculado al mito de la frontera, metáfora del "sueño americano" que presentaba a los Estados Unidos de América como la nación destinada a expansionarse desde el Atlántico al Pacífico.

${ }^{42}$ Véase Neil Lerner, "Copland's music of wide open spaces: surveing the pastoral trope in Hollywood", The Musical Quarterly 85/3 (2001), pp. 477-511.

${ }^{43}$ Philip Tagg y Bob Clarida, Ten little title tunes. Towards a musicology of the mass media (New York \& Montreal: The Mass Media Music Scholars' Press, 2003), en su capítulo dedicado al análisis de El Virginiano, pp. 277-408, p. 303. Una anapho$n e$ es un tipo de signo homólogo (es decir, se refiere a algo que ya existe) desde el punto de vista sónico, cinético o táctil, que implica la imitación de modelos previos. Una anaphone sónica puede definirse como la estilización musical de sonidos que existen fuera del discurso de la música, por ejemplo los producidos por el cuerpo humano, animales o elementos del entorno natural. La anaphone cinética es una variante de la sónica, que a su vez contempla otras subcategorías (paralingüísticas, táctiles y espaciales). Véase P. Tagg, Music's Meanings. A modern musicology for non-musos (New York \& Montreal: The Mass Media Music Scholars' Press, 2013), pp. 486-487. Tagg parte de las investigaciones de Zofia Lissa (̈̈esthetik der Filmmusik, 1959) quien, desde un planteamiento estructuralista, sistematizó las funciones de la música en el cine y señaló la anaphone sónica como un recurso fundamental de la música cinematográfica. Aunque no viene en el diccionario de la RAE, he traducido el término como "anáfona". 
dicador de estilo debido a su reiterada aparición). ${ }^{44}$ Timothy E. Scheurer ha analizado las relaciones entre mito y música en el cine, y de qué forma la música contribuye a construir y comunicar las convenciones de los géneros cinematográficos, y ha identificado varios motivos, tópicos y gestos musicales que enfatizan tales convenciones, contradicciones y conflictos narrativos. Scheurer demuestra que la música funciona mitopoéticamente a través de dos recursos: de un lado, mediante la ubicación y repetición - de un tópico (convertido en símbolo), de un leitmotiv (convertido en signo indexical), o de marcas nemotécnicas que aseguran la continuidad y la comprensión de la narrativa - y, de otra parte, mediante el uso de las armonías y el color orquestal para construir tópicos sonoros. ${ }^{45}$

Teniendo en cuenta este marco teórico y metodológico, he realizado un análisis de las partituras conservadas y de las películas para identificar tópicos musicales, códigos audiovisuales y conexiones paratextuales, prestando atención a las relaciones entre música, imágenes y situaciones argumentales. ${ }^{46}$ El objetivo es observar cómo la música de Montorio produce significado en las narrativas fílmicas y contribuye a fortalecer los mitos del wéstern, así como identificar sus funciones épicas, emocionales, dramático-estructurales, perceptivas, cognitivas y estéticas desde un enfoque semiótico-funcional, teniendo en cuenta los trabajos de Claudia Gorbman, Claudia Bullerjahn, Anahid Kassabian, David Neumeyer, Emilio Audissino, además de las obras ya mencionadas de Kathreen Kalinak. ${ }^{47}$

${ }^{44}$ Ibid., pp. 326 y 357.

${ }^{45}$ Considerando los estudios sobre semiótica musical de Eero Tarasti, Robert Hatten y Caryl Flinn, Timothy E. Scheurer, Music and mythmaking in film. Genre and the role of the composer (Jefferson, NC: McFarland \& Company, 2005), pp. 140-175, identifica los tópicos musicales del wéstern, que mitifican el paisaje, el héroe, los villanos, la comunidad (el pueblo), la mujer, los salvajes y la idea de duelo. El autor coincide con Kalinak y reafirma la eficacia de la música como herramienta para conseguir que los espectadores acepten los valores ideológicos del wéstern en términos de raza, etnicidad, género y clase. Particularmente útil es el concepto de style topic, que puede definirse como un signo que ayuda a clarificar el significado de un tema musical, y que con frecuencia sirve para marcar la noción de "diferencia".

46 En cuestiones referentes a la relación entre música e imagen, he tenido en consideración la obra de Michel Chion, $L a$ audiovisión. Introducción a un análisis conjunto de la imagen y el sonido (Barcelona: Paidos, 1993).

47 Véanse Claudia Gorbman, Unheard melodies. Narrative film music (Bloomington, IN: Indiana University Press, 1987);
En líneas generales, la música de ambas películas responde a los estándares del wéstern clásico de serie B: idioma romántico, bloques de música sinfónica a gran orquesta con tuttis poderosos para escenas de persecución y enfrentamientos o para caracterizar a los villanos (con gran sutileza en el uso de maderas y metales, y armonías más oscuras y ambigüedad tonal), bloques musicales más ligeros instrumentados para piano, violín y banjo como sinécdoques de lugar, y uso abundante del underscoring privilegiando los diálogos. ${ }^{48}$ Asimismo, predomina la empatía y el paralelismo en relación con las imágenes, y se observa un alto grado de sincronización entre la música y la narrativa visual de modo que es habitual la coincidencia de cambios de plano con el inicio y el final de los bloques musicales. ${ }^{49}$

La naturaleza y funcionamiento de la música diegética (canciones), intradiegética (forma parte de la narrativa espacio-temporal de la fábula) y extradiegética (fondos sonoros no dictados por los eventos del espacio narrativo, que acompañan a la acción dramática y a los diálogos) de ambos filmes confirma que Montorio conocía bien los códigos audiovisuales del wéstern americano. ${ }^{50}$ Así, su

Claudia Bullerjahn, Grundlagen der Wirkung von Filmmusik (Augsburg: Wißner, 2007); Anahid Kassabian, Hearing film. Tracking identifications in contemporary Hollywood film music (New York: Routledge, 2001); David Neumeyer, Meaning and interpretation of music in cinema (Bloomington, IN: Indiana University Press, 2015); y Emilio Audissino, Film/Music analysis. A film studies approach (Cham, Suiza: Palgrave Macmillan, 2017).

${ }^{48}$ El término underscoring hace referencia a cómo la música extradiegética se entrelaza con los diálogos, acompañándolos sin estorbar e impedir una adecuada comprensión de los mismos, para lo cual se requiere una intensidad baja, de forma que el espectador puede, en ocasiones, no ser del todo consciente de su presencia.

49 Muchos compositores españoles de cine denominan "bloque musical" a cada uno de los fragmentos de música extradiegética o incidental que se suceden a lo largo del film, tal y como se comprueba en las partituras manuscritas y en los guiones, donde iban numerados según el orden de sucesión para facilitar el proceso de montaje.

${ }^{50}$ He utilizado las categorizaciones de Ben Winters en "The nondiegetic fallacy: film, music and narrative space", Music and Letters, 91/ 2 (2010), pp. 224-244. Winters plantea un concepto fílmico (y no narratológico) de la diégesis, que tiene menos que ver con la narración que con el espacio narrativo, rechaza la categoría convencional de "no-diegética" y plantea no sólo un cambio de vocabulario sino conceptual. Para solucionar la convencional oposición entre diégesis y no diégesis, hay una pluralidad de expresiones diegéticas que pueden concurrir en una 
música utiliza tópicos, leitmotiv, marcas nemotécnicas, gestos musicales narrativos, tópicos musicales asociados al cowboy y a los villanos, el tópico pastoral en momentos puntuales, anáfonas cinéticas y sinécdoques geográficas habituales en el género.

En ambos filmes funcionan los códigos morales del wéstern y unos marcos narrativos convencionales donde los mitos del género dialogan con la música. En Los cuatreros la dicotomía héroe/villano es muy clara, lo que se subraya con la música gracias a un uso consciente de varios leitmotiv estratégicos: temas para al héroe (Jim), la mujer (Mary) y los cuatreros (y, por extensión, Lad, como jefe de la banda), sometidos a algunas variaciones en varios bloques musicales a medida que transcurre la acción, que clarifican el triángulo sentimental y subrayan la narrativa maniquea del bien y el mal. La mayor complejidad narrativa y psicológica de Relevo para un pistolero exige una banda sonora diferente, de modo que Montorio renuncia a caracterizar a los protagonistas masculinos (héroe y antihéroe) mediante leitmotivs contundentes, breves y discernibles por el espectador, sometidos a la repetición y la variación, que es una exigencia consustancial a la técnica. ${ }^{51}$

En las películas no hay indios, que en el wéstern americano tienen unos códigos musicales muy específicos. ${ }^{52} \mathrm{Sin}$

película: intradiegética (juega un papel activo en la diégesis fílmica), metadiegética (se percibe como si procediera del interior de los personajes), transdiegética (comienza como una diégesis y se convierte en un fondo sonoro) y extra-diegética, que he utilizado. Véase también Emile Wennekes, "Out of tune? Jazz, Film and the Diegesis", en Cinema changes: incorporations of jazz in the film soundtrack, ed. Emilio Audissino y Emile Wennekes (Turnhout: Brepols, 2019), pp. 3-18, 11. Un análisis en profundidad sobre estas cuestiones, desde una perspectiva narratológica, puede consultarse en Guido Heldt, Music and leves of narration in film. Steps across the border (Bristol: Intellect, 2013), p. 49 y ss.

51 Justin London, "Leitmotifs and musical reference in the classical film score", en Music and cinema, ed. James Buhler, Caryl Flinn y David Neumeyer (Middletown, CT: Wesleyan University Press, 2000), pp. 85-96, 92.

52 Véanse Michael Pisani, "I'm and indian, too': creating native American identities in Nineteenth and early TwentiethCentury music", en The exotic in Western music, ed. Jonathan Bellman (Boston: Northeastern University Press, 1998), pp. 218-257; y Claudia Gorbman, "Scoring the indian: music in the liberal Western", en Western music and its others: difference, representation and appropiation in music, ed. Georgina Born y David Hesmondhalgh (Berkeley, CA: University of California Press, 2000), pp. 234-253. embargo, es interesante destacar que la música que acompaña a las fechorías de la banda de Dylon (en Relevo) y a los cuatreros, instrumentada a gran orquesta, utiliza tópicos sonoros similares que representan "al otro" y connotan amenaza: acentuaciones fuera de tiempo, disonancias, melodías angulares y nerviosas que a veces carecen de centro tonal, notas repetidas, tresillos rápidos, cromatismos, trémolos en las cuerdas, protagonismo de los metales, es decir style topics asociados al mal y a los villanos en el cine americano. ${ }^{53}$ Asimismo, en Los cuatreros, los villanos se asocian a los timbres de las trompas, trombones y el clarinete bajo (pues suelen actuar en la oscuridad), mientras que el motivo de Jim procede de un alegre fox vaquero que se va transformando a lo largo del film hasta alcanzar unas connotaciones épicas gracias a la orquestación y la variación rítmica: de este modo, se produce un contraste musical que contribuye a articular la agencia del héroe. ${ }^{54}$

También comprobamos la influencia de la música de las cue sheets y kinotheks del cine mudo para ilustrar persecuciones, cabalgadas y peleas, como en el cine americano. ${ }^{55}$ Con todo, varias peleas no van acompañadas de música extradiegética, sino que Torrado optó por una diégesis real, con jadeos, golpes, gritos, relinchos - en el caso de Los cuatreros-, algo que también ocurre en algunas escenas rodadas en exteriores, renunciando al empleo del tópico pastoral: de hecho, en Los cuatreros se suprimieron varios bloques musicales inicialmente previstos, como se comprueba en las partituras manuscritas y los guiones.

Los dos filmes comienzan con un prólogo sin música de unos 3 minutos, anterior a los títulos de crédito. En Relevo se muestra la vida anterior de Relámpago Harris y su banda, que atracan un banco y asesinan al sheriff. En Los cuatreros se plantea el conflicto argumental primario: representantes del gobierno acusan al recio ranchero de ser responsable del tráfico ilegal de ganado a través de la frontera. Es interesante cómo Montorio plantea la música de los títulos de crédito, a gran orquesta en ambos casos. En Relevo se muestran unas panorámicas de una pradera donde se ve una diligencia (plano largo, código habitual del género) que alterna con planos medios de

53 Scheurer, Music and mythmaking in film, p. 156.

54 Scheurer, Music and mythmaking in film, p. 16.

${ }_{55}$ El término cue se refiere a un punto de señalización que marca el principio y final de un evento sonoro. De ahí que se conocieran con el nombre de cue sheet a unos folletos que marcaban las entradas (cue) de la música de una película, y que incluían recopilaciones de fragmentos musicales originales o adaptados, para servir de guía a los músicos que trabajaban en las salas de cine. 

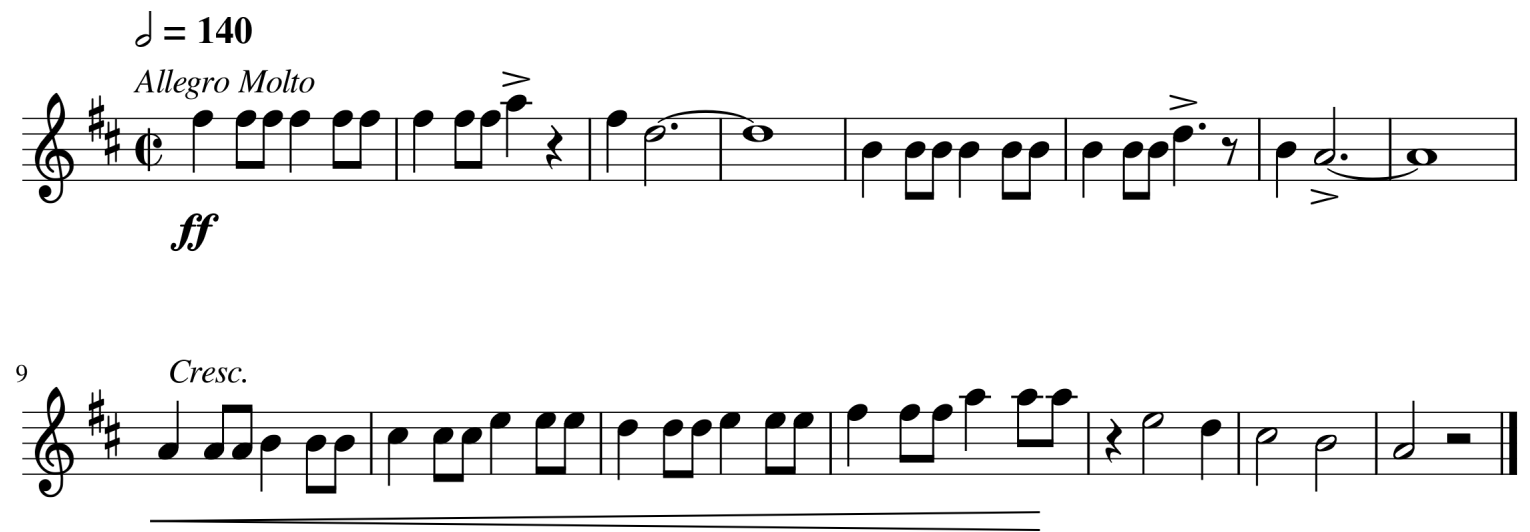

Ejemplo 1. Relevo para un pistolero: música para los títulos de crédito (tema principal, trompetas).

los caballos y los cocheros (bloque 1: 3:04-5:15). Tras una escala ascendente en las cuerdas (Allegro molto), se presenta el tema principal en las trompetas en Re mayor (véase Ejemplo 1), caracterizado por un motivo rítmico que funciona como signo icónico o anáfona equina (negra +2 corcheas en un 2/2), subrayado por la Temple Block en la batería.

Este ostinato en la batería puede ser una alusión a los títulos de crédito de Stagecoach (John Ford, 1939) con sus ritmos de galope, o a la música de algunos ballets de Aaron Copland, muy influyentes en el wéstern clásico: el motivo está presente en Rodeo (V. Hoe Down) y en el "Mexican Dance" del ballet Billy the Kid. El tema se repite en los trombones en Si bemol mayor, también muy enérgico, lo retoman los violines con una leve variación rítmica y adquiere un significado sinecdocal (frontera con México). Así, a lo largo del bloque musical, de estructura episódica, se repite el tema principal, modificando el color y las armonías. Asimismo, se comprueba la influencia de las músicas de los Wild West Shows (tópico militar) y un movimiento secuencial acumulativo (armónico ascendente) para crear tensión, con contramotivos sincopados en los metales cuando el tema lo lleva la cuerda, como ocurre en algunas entradas de las cue sheets del cine mudo (Galloping y Hurry).

El tema principal de la cabecera de Relevo reaparece al final de la película, transformado y en aumentación en los metales, trágico: tras matar a Edwin, Relámpago arroja el cinturón con los revólveres al suelo y se aleja por la calle del pueblo (se sobreimpresiona la palabra FIN). Por tanto, Montorio pone en funcionamiento un recurso habitual en Hollywood, utilizado en The Searchers (John Ford, 1956, música de Max Steiner) y Río Bravo (Howard
Hawks, 1959, música de Dimitri Tiomkin), que finalizan con una música similar a la de los créditos.

En Los cuatreros, la música de los títulos de crédito (bloque 1: 2:53-5:06), en la tonalidad de Re mayor como en Relevo, acompaña a unas panorámicas que muestran a un solitario jinete cabalgando por la pradera y las rocas escarpadas del Oeste en plano largo: tras unos compases introductorios - un trino prolongado en cuerdas y flautas y unos motivos breves en los metales, que recuerdan a los compases iniciales de los créditos de Río Grande de John Ford, con música de Víctor Young (1950)-, se presenta el tema principal en la cuerda, lírico, sincopado y con unos contramotivos en los metales que generan un expresivo contrapunto rítmico, fiel a los estereotipos que había reactualizado The Big Country (William Wyler, 1958) con música de Jerome Moross. La melodía, acompañada de armonías plagales, tiene energía rítmica y vitalidad a través de las síncopas, los crescendos y saltos melódicos ascendentes de $4^{\mathrm{a}}$ justa, de connotaciones épicas bajo la influencia del tópico pastoral, una convención de género al igual que la cabalgada del jinete en plano largo. ${ }^{56} \mathrm{De}$ nuevo Montorio introduce un ostinato en la caja, basado en el ritmo de galope: un signo icónico que se repite en los finales de frase.

El resultado es una especie de obertura donde como ocurrió en Relevo - se repite de forma reiterada el tema principal. Para finalizar el bloque, suenan unos compases en tutti, de tono épico, con un motivo nuevo que no es otro que la cabeza del tema de Jim en un transparente modo mayor, con unos acordes brillantes en los

56 Scheurer, Music and mythmaking in film, pp. 142-143. 

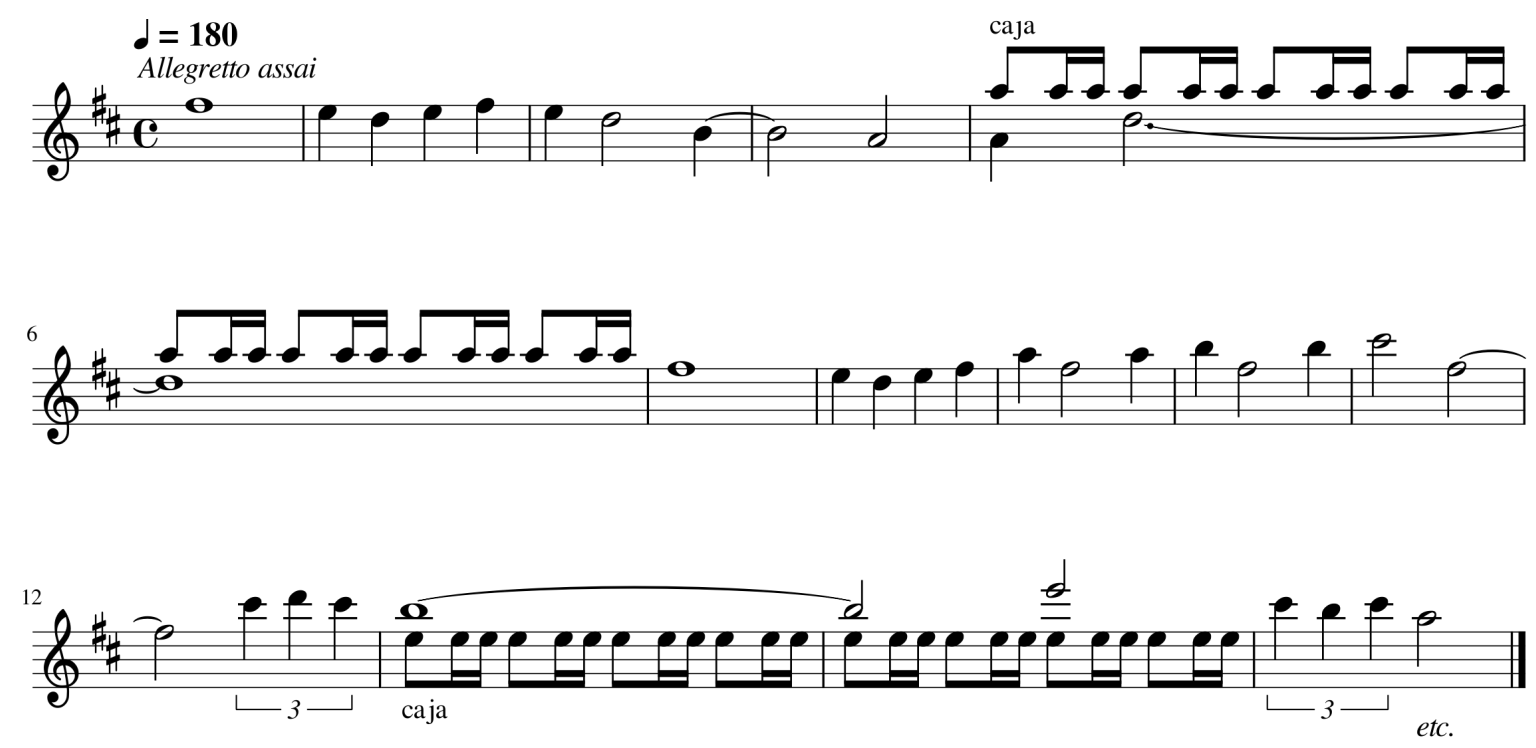

Ejemplo 2. Los cuatreros: música para los títulos de crédito (tema principal, violines).

metales mientras la pantalla muestra un plano medio de la silueta del jinete (Jim) que se recorta contra el cielo del anochecer, otra convención del género.

Por tanto, para las músicas de los títulos de crédito Montorio rechaza el modelo de High Noon (1952), The Searchers (1956) o Río Bravo (1959), rehúye el protagonismo de la canción popular, y se aproxima al scoring topográfico de The Big Country (1958). Este hecho sugiere la influencia de Jerome Moross, que se confirma a medida que avanzan las narrativas de ambas películas, ya que Montorio pone más énfasis en subrayar las atmósferas (dramáticas, topográficas e identitarias) y la acción que en caracterizar emocional y psicológicamente a los personajes, algo habitual en la música de cine del compositor estadounidense. ${ }^{57}$

Pese a que los dos filmes presentan códigos audiovisuales compartidos, hay también diferencias interesantes. La más notable se refiere a la presencia de canciones populares: cuatro en Relevo frente a una en Los cuatreros. En Relevo dos canciones son interpretadas por Ann en el Saloon Paradise: Tú serás (un slow con letra de Manuel Paso) y Dígame usted (cuplé con cantables de Ra-

57 Mariana Whitmer, "Reinventing the Western film score: Jerome Moross and The Big Country", en Music in the Western. Notes from the frontier, ed. Kathryn Kalinak (New York: Routledge, 2012), pp. 51-76, 73. món Torrado). Las otras dos son canciones mexicanas: la ranchera Tequila, limón y sal (letra de Luis Gaspar y Ramón Torrado) que canta Carmen, y Cuando estoy lejos de ti (cantables de Torrado) interpretada por el Trío Los Payadores, ambas en el bar de los mexicanos (el Pulque).

Unos mexicanos cantan Cuando estoy lejos de ti mientras Edwin visita el Pulque. Torrado y Montorio presentan una secuencia de diégesis fluida: la canción es diegética e intradiegética, a veces acompaña a los diálogos (underscoring) y cumple una función de raccord para proporcionar continuidad a los frecuentes cambios de plano de Carmen, su novio Miguel y Raúl, modificándose los planos de escucha cuando los hombres entran al despacho a conversar. Carmen también canta Tequila, limón y sal en el Pulque; en este caso, el tema tiene una función dramático-narrativa ya que presagia el drama y la obsesión posterior de Edwin por Carmen. Aunque se presenta como canción incidental e interrumpe brevemente la acción, esta ranchera es la base del tema que Montorio adjudica a Carmen en la música extradiegética: es el único tema que entiendo puede considerase un leitmotiv en el film, lo que se explica porque lo que va a acabar con la humanidad (y con la vida) de Edwin será su obsesión por la joven, el único personaje completamente limpio de la trama y, quizás por ello, el único que merece un tema que le singularice.

En el Paradise hay tres números metateatrales, prescindibles desde el punto de vista narrativo. El primero es 
un baile a ritmo de fox-trot rápido a cargo de las chicas del Saloon. El segundo es un número que canta Ann (Tú serás), un slow con aire de feeling (muy de moda a mediados de los años sesenta): el tema (en source scoring como es habitual en el cine musical) está pensado para el lucimiento de la cantante, quien intenta seducir a Edwin..$^{58}$ Ann también interpreta un cuplé sin relación con la trama, interrumpido bruscamente por la entrada de Edwin alterado en el local. Este cuplé de letra picaresca (anotado como "cursi" por el autor en el manuscrito) confirma la influencia de la revista española que Montorio conocía bien, y que también está presente en Los cuatreros. En Los cuatreros sólo hay una canción metateatral, interpretada por La Bella Katherine: Mi cariño es oro. Se trata de un fox vaquero que canta la vedete acompañada de seis coristas, todas disfrazadas de "vaqueritas" con minifaldas a la manera de las vicetiples de una revista teatral. Resulta un número más vulgar que los de Relevo: aunque detiene brevemente la trama narrativa, la canción está justificada en la presentación de Katherine, que hará posible la huida de Jim de la cárcel.

Tras este análisis general comparativo, a continuación mostramos los detalles más relevantes de ambas películas. En los Apéndices 1 y 2 pueden consultarse las tablas con las entradas musicales donde se detalla el minutaje, bloques musicales, fuente, eventos sonoros y elementos narrativos de las tramas.

\section{RELEVO PARA UN PISTOLERO}

Relevo para un pistolero presenta 20 bloques musicales de música extradiegética e intradiegética, incluidos los créditos de inicio y fin, con un total de unos 28 minutos: en el proceso de montaje se suprimieron dos bloques, y algunos son muy breves y circunstanciales. En ellos he distinguido tres temas importantes: el tema

\footnotetext{
58 Source scoring es un concepto utilizado en 1971 por Earle Hagen en su libro Scoring for Films, para referirse a la combinación de música diegética (lo que denomina source music) y extradiegética (lo que define como source scoring) en una secuencia. Es un recurso muy habitual en el musical cinematográfico y en algunos números musicales donde - como ocurre en este caso - la voz de la cantante es diegética, pero no así el acompañamiento de la orquesta. Anahid Kassabian, Hearing film. Tracking identifications in contemporary Hollywood film music (New York: Routledge, 2001), propone este término para referirse a un estado intermedio entre la diégesis y la no diégesis, una especie de estatus abierto, si bien desde la percepción del oyente esto no es relevante.
}

de Blacktown (símbolo de civilización, pero localizado en el Oeste, conquistado por los colonos), el tema de la tienda Jackson Store (simboliza la industriosidad que viene del Este) y el tema de Carmen. Ann no tiene tema propio en los fondos sonoros. Podría pensarse en los temas de Blackstone y de la tienda como alusivos a Relámpago y Edwin Jackson respectivamente: pero no son épicos, no tienen fuerza, apenas tienen desarrollo dramático-narrativo, y no son identificables fácilmente por parte del espectador, a diferencia de lo que ocurre con el motivo de Jim en Los cuatreros. Porque Jim es un héroe, indiscutiblemente.

En Relevo para un pistolero, tras el bloque de los títulos de crédito la música reaparece con la presentación del tema de la tienda en el bloque 2 (13:07-15:56): un dinámico aire de danza en violines y piano, en Do mayor, que recuerda ligeramente a un galop, al que se une más tarde el banjo como sinécdoque convencional. El tema de Jackson Store alterna con un tema circunstancial: otro aire de danza, ligero, parecido a una polka, con cambio de metro y tonalidad, para caracterizar a las alegres y coquetas chicas del Saloon, primeras clientas del local. La secuencia es importante porque muestra la inocencia de Edwin: la música acompaña la acción, mientras las chicas se mofan de él. El tema de Blacktown se presenta en el bloque 5 (22:33-25:20): es una melodía sencilla, un $f o x$ para banjo y orquesta pequeña que acompaña a un diálogo muy importante (underscoring). Relámpago cuenta a Edwin su historia de crimen, cárcel y arrepentimiento: durante el diálogo, suena el tema de Blacktown en el trombón justo cuando el pistolero dice "Ya ves, he cambiado", creando un expresivo contraste entre la redención del héroe y la ligereza de la melodía. Montorio planifica un expresivo contraste musical: aires de danza de origen europeo (galop y polka) para la tienda y sus clientas (en alusión al progreso pero también al ocio, mujeres frívolas, atrevidas y sofisticadas) frente a un fox vaquero para el pueblo de colonos e indirectamente para Relámpago, es decir el Este frente al Oeste.

El tema de la tienda reaparece en el bloque 11 (58:59-1:00:31) cuando Edwin contempla su local destrozado por la banda de Dylon. Una orquesta pequeña interpreta una variación acorde con la situación narrativa: en tempo muy lento (indicación de "muy triste" en los manuscritos), el tema aparece en flauta y clarinete en Sol menor (ya no en Do mayor) con un acompañamiento sincopado en la cuerda. La música acompaña el diálogo en el que Relámpago intenta animarle y le propone hacerse sheriff del pueblo, preciso momento en que trompetas y trombones introducen un contramotivo, más épico, segui- 
do una variación del tema de Blacktown. Pero Edwin rechaza la propuesta ("solo vine al Oeste a hacer fortuna") y la música regresa a la variación del tema de la tienda, como símbolo de prosperidad y del Este: el bloque finaliza en un Mi bemol (VI grado) con $7^{\mathrm{a}}$, no conclusivo, cuando Relámpago sale de la tienda, dejando la resolución del conflicto en el aire.

En el wéstern americano, las mujeres (en tanto símbolo primario de civilización) suelen tener temas románticos, con cuerdas amables, sentimentalismo y gracia (para simbolizar la domesticación de la violencia y lo salvaje).$^{59}$ De este modo, el wéstern opera con lo que Kassabian denomina "identificaciones asimilantes" mediante las cuales los personajes femeninos están ligados a la naturaleza, la intimidad y la categoría del romance. ${ }^{60}$ Esto se comprueba, como veremos, en el tema de Mary en Los cuatreros, pero en el caso de Carmen Montorio se decanta por una opción distinta: elige para la joven la música de la ranchera Tequila, limón y sal, cuyo texto narra la historia de de una mujer abandonada por su amante y que sólo ansía emborracharse con tequila para olvidar su tristeza, como expresa en el refrán. senta el tema de Carmen en la música extradiegética, lo llevan las cuerdas, suaves y amables, como el personaje al que caracteriza, de tal forma que se reafirman los mecanismos patriarcales convencionales. ${ }^{61}$ Así ocurre en el bloque 13 (1:05:28-1:07:00), una vez que Edwin Jackson se ha convertido en dueño del pueblo: la música (underscoring) suena muy suave - Montorio anotó "amoroso" en la partitura-, con el tema de Carmen en la cuerda, en Re mayor, mientras Jackson se insinúa y ella le rechaza (véase Ejemplo 3).

El tema de Carmen reaparece en el bloque 15 (1:12:54-1:13:28), "triste" (en el manuscrito), instrumentado para piano, violín, banjo y contrabajo, ahora en Do Mayor y en un registro más agudo, mientras Edwin camina por la calle, malhumorado, tras una discusión con Carmen, pensando en ella, de modo que la música tiene una función cognitiva. La cabeza del tema de Carmen regresa al principio del bloque 17 (1:19:10-1:22:47), ahora en clarinetes, mientras Edwin, borracho, se dirige a la tienda: de nuevo la música tiene una función cognitiva, pues Edwin está pensando en la joven mexicana, y no parece tener buenas intenciones.

\section{Refrán}

Quiero volver a tomar tequila, limón y sal pa emborracharme más pronto y así poderte olvidar.

\section{Estrofa $1^{\mathrm{a}}$}

Yo me enamoré de ti creyendo que me querías y a pesar de que mentías mi vida entera te di.

\section{Estrofa $2^{\mathrm{a}}$}

He sido mujer de un día capricho que nace y muere y hoy el corazón me duele de tanto que te quería.
El desamor y la traición son asuntos tradicionalmente abordados en la copla de amores imposibles, y Carmen entona este tema en el que la protagonista de la canción decide consolar sus penas bebiendo tequila mientras Edwin, de hecho, está emborrachándose contemplando a la joven: con la canción, Carmen despierta su interés, y seduce al joven sin pretenderlo, pues ella es viva imagen de la ingenuidad. Al utilizar una canción popular para caracterizar a la joven mexicana, Montorio pone en funcionamiento unos mecanismos significativos que proponen un abanico más amplio de interpretaciones: entre ellas el empoderamiento femenino, si bien el precio es la muerte, de modo que Carmen se convierte en víctima inocente, como muchas mujeres de copla. Con todo, cuando se pre-

\footnotetext{
59 Scheurer, Music and mythmaking, p. 154.

${ }^{60}$ Kassabian, Hearing film, p. 31 y ss.
}

Montorio diseña unos motivos musicales de sonoridad oscura y disonante que se asocian a la banda de Dylon y aparecen en el bloque 7 (45:20-47:13), cuando los forajidos matan a Raúl y pretenden forzar a Carmen, que intenta escapar: instrumentado para orquesta grande, el bloque presenta unos tópicos musicales habituales en situaciones de persecución o peligro, con un omnipresente acompañamiento en tresillos urgentes, y un gran trabajo tímbrico que sirve para acentuar el dramatismo de las imágenes violentas. La música es empática, de naturaleza plástica y tiene función dramático-narrativa: comienza con un motivo descendente en semicorcheas rápidas, por

\footnotetext{
${ }^{61}$ Estaba previsto un bloque 6 (de 23 segundos de duración, para violín, piano, guitarra y bajo, en Do mayor y en registro agudo) donde se presentaba el tema de Carmen, que fue suprimido, quizá por haberse eliminado una secuencia anterior al asesinato de Raúl. Esta música se reutiliza en el bloque 15.
} 

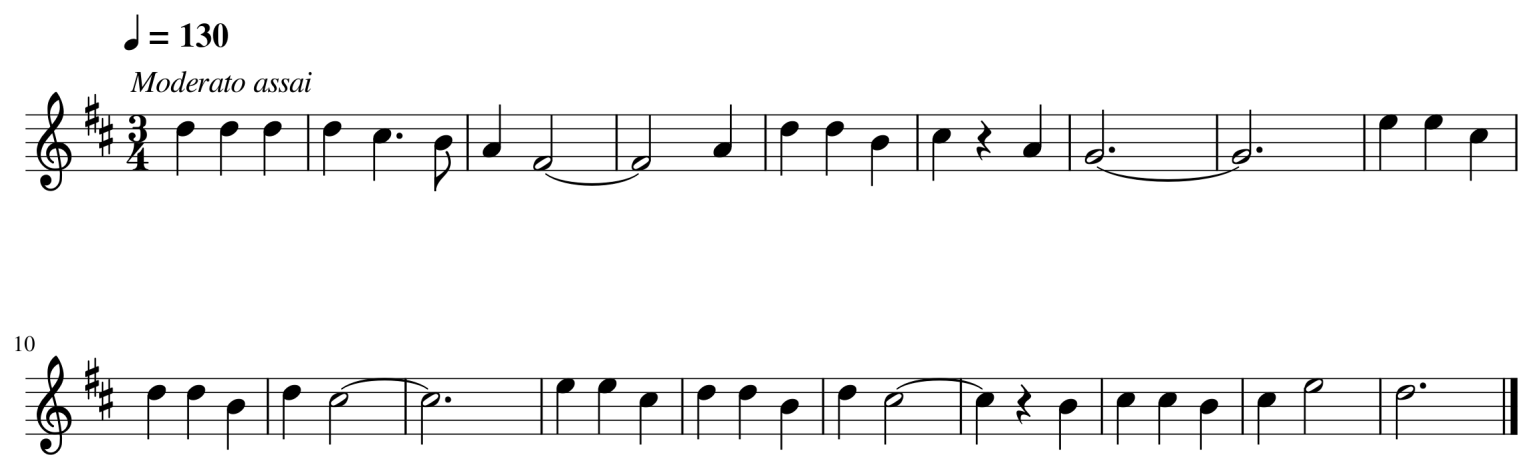

Ejemplo 3. Relevo para un pistolero: tema de Carmen (violines, bloque 13).
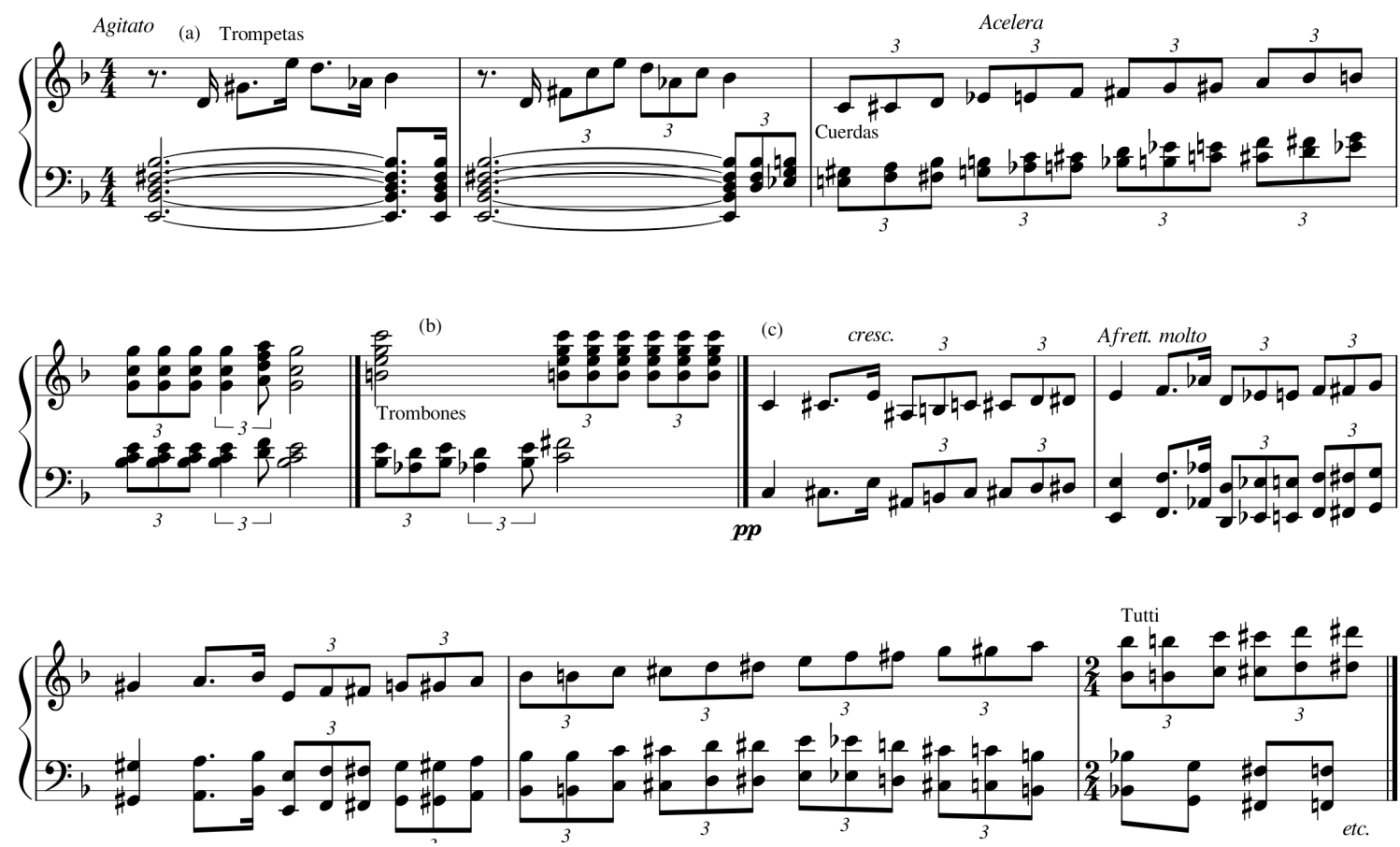

Ejemplo 4. Relevo para un pistolero, motivos de la banda de Dylon (reducción para piano, bloque 7).

semitonos, mientras Raúl cae por la escalera tras recibir un disparo de muerte. En este bloque (véase Ejemplo 4) hay varias aspectos a señalar: (a) un motivo estridente en las trompetas en el que destaca el intervalo de tritono descendente (acompañado de un acorde con $5^{\mathrm{a}}$ aumentada) que continúan las cuerdas en urgentes tresillos cromáticos ascendentes (acelerando); trémolos y acordes de $6^{\mathrm{a}}$ aumentada en la cuerda con una línea del bajo que destaca un salto interválico ascendente de tritono mientras inician la búsqueda de Carmen por las habitaciones (no en el ejemplo); (b) una célula motívica en trombones que reaparece varias veces; (c) un rápido ascenso cromático de ritmo nervioso también con tresillos (crescendo y afrett. molto) sobre un pedal en Mi en trémolos mientras Carmen huye.

Cuando la banda de Dylon derriba la puerta de la habitación de Carmen, y descubren que ha huido por la ventana, los trombones (crescendo) adquieren protago- 
nismo melódico con un tema arpegiado que cobra dramatismo a medida que asciende en registro mientras buscan una escalera para bajar a la tienda. La música, dramática, también cumple una función de raccord para unir planos rápidos de esta secuencia y la siguiente: el incendio, el destrozo, Carmen escondida y horrorizada, los mexicanos intentando apagar el fuego. Fragmentos de la música del bloque 7 son utilizados en el bloque 12 (1:02:17-1:04:19), durante el enfrentamiento entre Edwin con la banda de Dylon: de nuevo, la música tiene una función dramática, y aporta continuidad a los distintos planos de la lucha, a muerte, finalizando con un acorde de $7^{\mathrm{a}}$ sin resolución.

El bloque 17 es muy importante (1:19:10-1:22:47): Edwin pasea por la calle pensando en Carmen (tras un descenso cromático, suena el tema de Carmen en clarinetes, como hemos señalado), y decide ir a la tienda (momento en que se llega al clímax orquestal). La música es metadiegética, trasladando al espectador los pensamientos turbios del protagonista, lo que se comunica mediante un motivo en los trombones acompañado por el timbal amenazador. Un nuevo tema en tutti (clímax de registro en las cuerdas y flautas) con timbal y batería anticipa la tragedia, y finaliza con un plano medio de Carmen sola en la tienda (motivos cromáticos en la cuerda, trémolos). La música está en perfecta sincronización con las imágenes y es empática, iniciándose el underscoring mientras ella le comunica que abandona el trabajo en la tienda. A lo largo de la secuencia, la música gana en tensión a medida que Edwin se va alterando más, reprocha a Carmen su ingratitud y que le comparen con Dylon: cuando menciona el nombre de Dylon, suena un motivo amenazador en los trombones y las trompas que, tras un redoble de timbal en crescendo, finaliza con un golpe musical. De hecho, este motivo reaparece en el bloque 18 justo antes de que Miguel descubra el cadáver de Carmen (trompa amenazante $\mathrm{y}$ acorde disonante al ver el cuerpo).

La frase "tú no te vas" de Edwin inicia un episodio nuevo (Agitato) en tutti, con un golpe musical que precede el contacto físico y el forcejeo ("Carmen, tú eres lo único que no he podido conseguir, lo único que se ha resistido a mi poder, soy el amo"): Montorio recurre a los urgentes tresillos durante el forcejeo y huida de Carmen, que se encierra en el almacén. En el momento en que Edwin derriba la puerta, se escuchan los compases con acordes de $6^{\mathrm{a}}$ aumentada del bloque 7 (cuando la banda de Dylon buscaba a Carmen). Los timbales resultan amenazadores mientras él se acerca, se abalanza, intenta forzarla, besarla y la mata: la música se va calmando y él la deja en el suelo. Este bloque (función dramática y narrativa) es muy importante semióticamente porque la música, gracias a un style topic vinculado a Dylon, equipara la maldad de Edwin y de Dylon, simboliza la claudicación del joven del Este, convertido en un villano más, corrompido por el poder y la violencia.

Los mexicanos están caracterizados a través de música de mariachi, y el Paradise con música diegética o intradiegética que consiste en fox-trot y música alegre de danza, a menudo para piano, banjo, violín o bien orquestina. Destaca el bloque 14A (1:09:32-1:10:49): un slow intradiegético al piano, batería, contrabajo y banjo mientras Relámpago bebe en la barra del Paradise, que introduce un recuerdo del tema de Blacktown en la batería y el banjo. Por tanto, Montorio opta por una música de connotaciones urbanas y ritmos derivados del ragtime para caracterizar al Saloon del pueblo, como era frecuente en el wéstern. Esto confirma que Montorio conoce las convenciones del wéstern americano, donde para crear un sentimiento de pueblo era habitual utilizar música diegética. La música incidental presenta bloques más breves y circunstanciales que ilustran algunas cabalgadas (bloque 3 , bloque 9 , bloque 10), bajo la influencia de la música del cine mudo.

\section{LOS CUATREROS}

Los cuatreros presenta un total de 32 bloques de música extradiegética e intradiegética (que incluyen varios fox vaqueros), de los cuales se suprimieron 9 en el proceso de montaje, algunos brevísimos. Como ya adelantamos, en ellos se aprecian tres temas para Jim, Mary y cuatreros, que articulan de forma clara la bipolaridad maniquea entre civilización/corrupción, entre el bien y el mal. Los fondos sonoros tienen una duración de $32 \mathrm{mi}-$ nutos y medio - es decir, unos 5 minutos más que Relevo - lo que permite a Montorio elaborar una partitura en la que los tres leitmotivs protagonizan un eficaz recorrido dramático-musical, en especial el tema de Jim. Como era habitual en el wéstern, la cabeza del tema del héroe se introduce en los créditos - en este caso en los compases finales, aunque no sea perceptible por los espectadores en ese momento - y reaparece en el último bloque musical donde se percibe de modo contundente, en modo mayor, épico y a toda orquesta con el protagonismo de los metales, mientras se sobreimpresiona la palabra FIN.

En Los cuatreros, Jim es el galán y protagonista absoluto, y a este personaje se adjudica un leitmotiv que es el más importante de la banda sonora musical: un fox vaquero con una característica figuración en puntillo, sincopado y con un diseño melódico pentatónico. De este modo, para caracterizar a Jim Montorio utiliza un style 


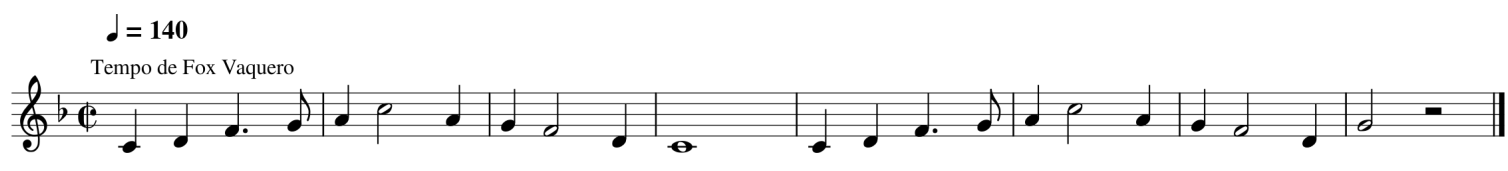

Ejemplo 5. Los cuatreros: tema de Jim (banjo o violín, bloque 3).

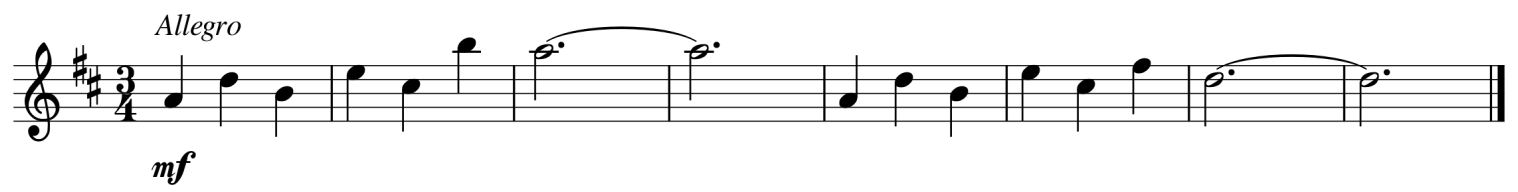

Ejemplo 6. Los cuatreros: tema de Mary (violines, bloque 10).

topic asociado al cowboy. Aunque el tema no está en modo menor, como es habitual, sino en mayor $(\mathrm{Fa})$, destaca el diseño melódico ascendente y positivo en las primeras notas, como suele ocurrir en los motivos asociados al héroe; quizá esto se deba a que, como se descubrirá al final, Jim no es un cowboy sino un militar. El tema de Jim se presenta completo en el bloque 3, ágil, interpretado por piano y banjo, añadiéndose el violín cuando Jim entra en el Saloon; véase Ejemplo 5. El tema no es épico, sólo adquiere esa condición a medida que transcurre el film; con la repetición y sucesivas variaciones se convertirá en signo indexical con connotaciones míticas gracias, sobre todo, a la instrumentación y a cambios en el ritmo/metro.

El tema de Jim aparece en varias ocasiones: bloque 6 (en el Saloon, fox vaquero para piano solo), bloque 10A (donde alterna con el tema de Mary, en una secuencia en exteriores en la que la pareja conversa sobre su vida sentimental), bloque 16 (cuando Jim se enfrenta a los cuatreros, arropado por los relinchos de los caballos), bloque 17 (variación rítmica del tema en el clarinete, mientras Jim vuelve en sí después de que los cuatreros le hayan golpeado), bloque 20 (cuando Pancho y Jim se dirigen a caballo a la guarida de los cuatreros), bloque 26 (en el cementerio cuando Mary está arrodillada rezando en la tumba de Jim) y bloque 32 (mientras la pareja se besa, por fin, momento en que suena épico, triunfante, en los metales).

Es en el bloque 20 (49:48-50:42) cuando el tema de Jim se hace definitivamente heroico. La música, para orquesta grande, presenta una fanfarria en los metales, un toque de trompeta (mientras se ven panorámicas de los riscos) seguido de una variación del tema de Jim (en las trompas, marcial) mientras este le cuenta a Pancho cómo se deshizo de los soldados (plano general de los jinetes con el fondo del paisaje salvaje). Pancho contesta: "Qué pedazo de macho eres, hombres como tú son los que necesita el jefe". Tras la repetición de la fanfarria ("ya verás cuando se lo cuente al jefe"), suena de nuevo el tema de Jim en las trompas, heroico, arropado por un toque de corneta, mientras los jinetes se internan en un desfiladero. De este modo, el tópico militar se asocia a la masculinidad heroica del protagonista y se articulan mecanismos patriarcales habituales en el cine clásico americano.

El tema de Mary es una melodía lírica en la cuerda siguiendo las convenciones del género. Aparece en el bloque 10 (23:31-24:31) para orquesta pequeña. Tras un pizzicato en las cuerdas (affrettando) el tema es romántico y ligero, en aire de vals con un acompañamiento tipo nocturno: se presenta en los violines y en Re mayor (véase Ejemplo 6), mientras las imágenes muestran un plano general de la pareja paseando a caballo, y tiene unos bonitos contramotivos en la madera (clarinetes y flauta) justo cuando ella le pregunta si está casado o tiene novia. A continuación, el tema se somete a un pequeño desarrollo en la cuerda y, para finalizar, Montorio usa una anáfona paralingüística como si la música respondiese a las risas de la chica con otra carcajada: motivo descendente muy rápido en clarinetes y flautas seguido de unos pizzicatos en notas ascendentes en las cuerdas. ${ }^{62}$

${ }^{62}$ Como muestra la documentación conservada, estaba previsto un bloque $1 \mathrm{~A}$ en el que se presentaba el tema de la joven, antes del primer fox vaquero, en una secuencia en la que Mary y su primo Lad conversaban; Montorio escribió un tema lírico en 
El bloque 10A (24:32-25:58) merece un comentario: comienza con un plano largo de un jinete que espía a la pareja (Lad). Montorio juega con los espectadores, ya que suena el tema de Jim lánguido, en clarinete y flauta, en Sol mayor y con armonías plagales. Quizá de manera sutil la música comunica el deseo de Lad de estar en el lugar de Jim, intimando con Mary. A continuación, entra el tema de Mary (en Si bemol mayor) que se encadena con el tema de Jim en los violines en Sol Mayor (ya no a ritmo de fox vaquero, sino más lírico) mientras la cámara muestra un plano general de la pareja a la orilla del río, lo que hacer prever el idilio amoroso. A lo largo del bloque, para orquesta pequeña, alternan los temas de Mary en el chelo (con contramotivos en la flauta), y el de Jim en clarinetes y flautas en underscoring, con un zoom de la cámara acercándose a la pareja mientras ella le confiesa que no quiere casarse con Lad, aunque a su padre le gustaría. Cuando Mary intenta coquetear con el nuevo capataz, suena el tema de Jim en el chelo. Jim no parece tomarla en serio, lo que la música confirma con detalles picarescos en clarinetes y flautas que ilustran la faceta traviesa de Jim. Mary se molesta, y regresa el tema de la joven en la cuerda mientras ella se aleja a caballo (fuera de plano) y él la observa.

Como ocurre en el wéstern, la mujer representa a la civilización y si son rubias (como en este caso) simbolizan también la pura feminidad ${ }^{63}$ algo que subraya la música de Montorio. El tema de Mary reaparece en los bloques 13, 26 y 27. Es importante el bloque 13 (30:1231:21), para orquesta pequeña, mientras Mary dialoga con su padre. Comienza con la cabeza del tema de Mary (ahora Moderato y en Sol mayor) en un solo de chelo que desarrolla y explota la función emotiva, subrayando el candor de Mary. Flauta y clarinete repiten el tema de Mary, respondido por los violines (donde sufre un breve desarrollo) mientras ella llora y, en rallentando, va muriendo en la cuerda a medida que Thompson le prohíbe a su hija cualquier roce con el capataz. Ella, obedientemente, acata su autoridad.

El bloque 26 (1:02:36-1:04:14) ilustra la secuencia en el cementerio, cuando regresa Jim al pueblo haciéndose pasar por su hermano gemelo. La música combina el tema de Jim, en legato, triste y lírico en las cuerdas (eliminadas las figuraciones en puntillo típicas del fox va-

la cuerda, un vals en $3 / 4$ y La bemol mayor, que se repetía en Do menor. Pero esta secuencia se suprimió, por lo que el tema de Mary retrasa su aparición y lo hace en otra tonalidad.

${ }^{63}$ Scheurer, Music and mythmaking in film, p. 154. quero), con un desarrollo del tema de Mary, muy sutil, en underscoring mientras Mary y el cura charlan sobre Jim, supuestamente muerto; el falso cura pretende averiguar los sentimientos de ella hacia Jim, mientras la música repite la variación del tema del héroe.

Mary cobra protagonismo en este tramo final del film, participando en importantes secuencias con Jim para la resolución del conflicto sentimental. De ese modo, aparece su tema en el bloque 27 (1:07:20-1:09:01): comienza mientras la cámara muestra un plano general de Jim y Mary en la calesa (tema de Mary en el clarinete, levemente variado, triste y expresivo, como el ánimo de Mary, que va de luto), luego caminan por la terraza del rancho y se sientan en el porche (suena un lírico solo de chelo, desarrollo del tema de Mary, triste, en violines) y ella se sincera con el falso cura, pues no desea casarse con Lad. Montorio utiliza deliberadamente la música del bloque 13 para la secuencia en la que Mary acataba los consejos de su padre, pues Mary pide consejo al falso cura. Música, imagen y diálogos están en perfecta sincronización en un eficaz underscoring. Los cambios de plano (de Mary a Jim) marcan las entradas de la cabeza del tema de Mary en clarinetes y flautas (mientras él le dice que afronte sin temor la situación) y del tema de Mary en los violines (registro agudo) en toda su extensión. Cuando llega el nuevo capataz a caballo termina el diálogo y ella se aleja por el porche mientras suena, rallentando, la cabeza de su tema en un solo de piano.

El tema de los cuatreros pasa más desapercibido para los espectadores, aunque no el sentimiento de amenaza, peligro y suspense al que va asociado gracias a la orquestación y a los tópicos musicales. La música de los cuatreros recuerda a la de los forajidos en Shane (George Stevens, 1953) con partitura de Victor Young; se presenta por primera vez en el bloque 4 (11:02-12:02) cuando los villanos se acercan a casa de Thompson en la oscuridad (véase Ejemplo 7). Hay tres motivos fundamentales en este bloque, caracterizado por la indefinición tonal: (a) un breve motivo introductorio en el clarinete bajo (compases 1 y 3 del ejempo) que alterna con las cuerdas graves (compás 2) y que connota suspense (de hecho, el maestro escribió en la partitura manuscrita la palabra "misterioso"); (b) un motivo en trompas, disjunto y nervioso y que termina con un salto descendente de $4^{\mathrm{a}}$ aumentada (un tritono), arropado por un trémolo en la cuerda que explota la tensión del intervalo de $2^{\mathrm{a}}$ menor (compases 6 y 8); y (c) una célula motívica de naturaleza cromática en el clarinete bajo (compases 10 y 12) en un expresivo salto ascendente y curvilíneo que finaliza en notas muy rápidas, de nuevo combinado con tresillos de corcheas en 

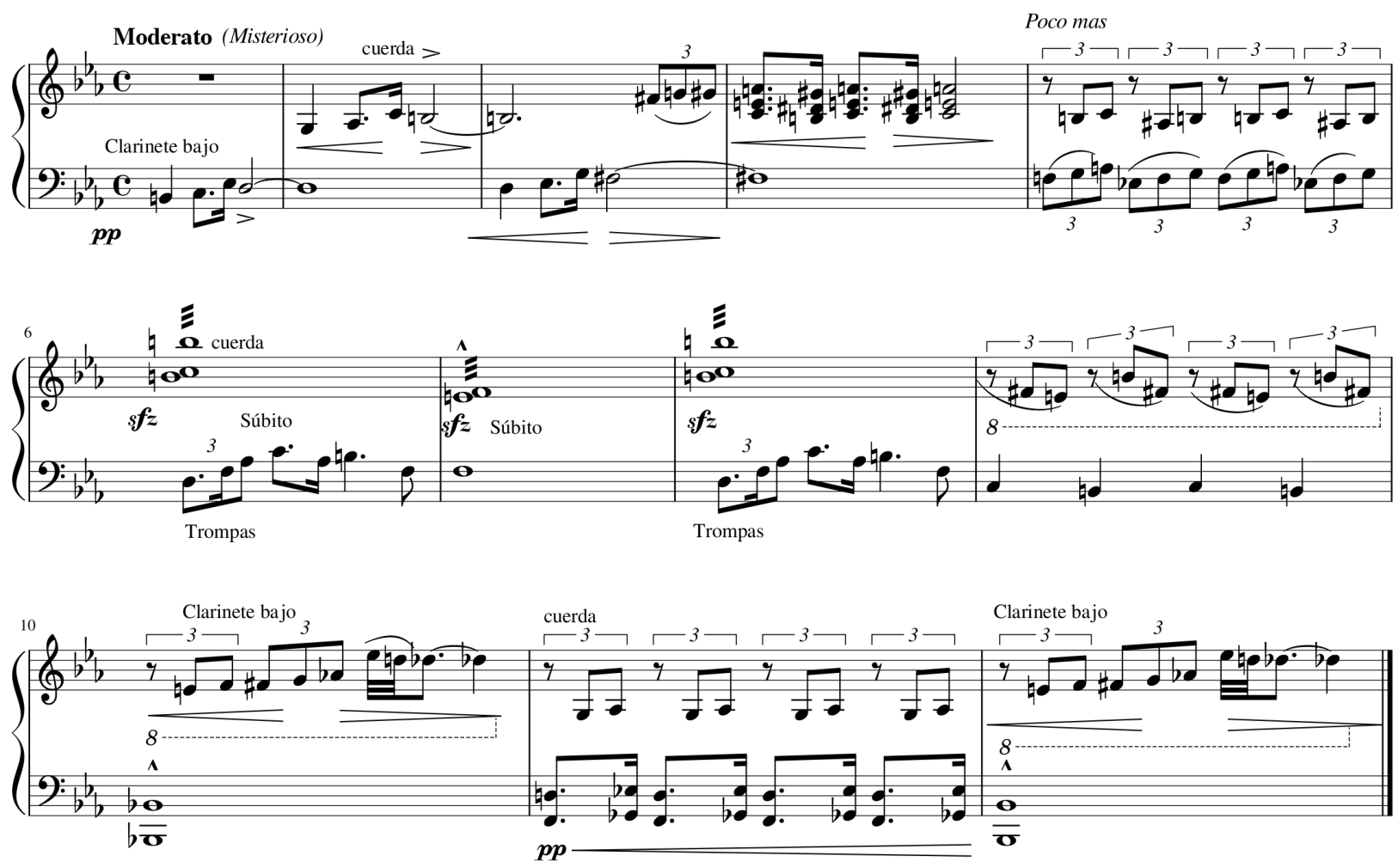

Ejemplo 7. Los cuatreros: motivos de los cuatreros (reducción para piano, bloque 4).

la cuerda. La música continúa con esta sonoridad oscura y las cuerdas retoman el motivo (b), que repiten varias veces, finalizando con varios gestos musicales habituales en las kinotheks del cine mudo para generar tensión.

La relación sustancial entre los villanos y las disonancias, con una instrumentación que explota el timbre de los metales y la persución, así como el poder expresivo de los tritonos, está presente en algunas bandas sonoras de Tiomkin de los años cincuenta, como en High Noon; se trata de tópicos musicales asociados a la idea de lo "salvaje" (the Wilderness) que caracteriza a la banda de Miller frente al lenguaje armónico consonante, armónicamente estable y rítmicamente predecible de la balada cowboy que representa al sheriff (the Garden). ${ }^{64}$ Una

${ }^{64}$ Jordan Carmalt Stokes, "The Western as national epic. Musical persona and narrative distance in High Noon", en $\mathrm{Mu}$ sic in epic film, ed. Stephen C. Meyer (New York, Routledge, 2017), pp. 210- 235, 225. El autor considera que las tensiones entre los tropos de Garden y Wilderness están en la base de las comparación entre los motivos musicales de Jim y los cuatreros confirma que la música articula la oposición entre héroe y villanos, el fox vaquero frente a la explotación de los timbres de la orquesta (en este caso también el clarinete bajo) en un estilo moderno que roza la atonalidad respectivamente, de forma que la música tiene un valor narrativo y cognitivo.

Los motivos que conforman la música asociada a los cuatreros son breves y plásticos, y aparecen en cuatro bloques más. En el bloque 16 (36:51-38:21) Montorio combina una variación del motivo (a) en cuerdas graves y clarinete bajo y el motivo (c), arropado con trémolos en la cuerda y que connota misterio y amenaza (los cuatreros se acercan a la empalizada en plena noche), con el tema de Jim (que se enfrenta a ellos) y luego con un tópico de música india. En el bloque 18 (39:49-40:43), para orquesta grande, el motivo (b) se repite varias veces

oposiciones binarias del wéstern: entre pueblo y desierto, trenes y caballos, granjeros y ganaderos, etc. 
(trombones, trompas), alterna con timbales y un travieso clarinete bajo mientras Lad registra la alforja para coger el cuchillo y el mexicano entra en otra cuadra para asesinar (fuera de cámara) a un hombre: la música tiene una función dramático-narrativa y cognitiva-denotativa pues comunica al espectador que se va a cometer (y comete) un asesinato sin necesidad de que la cámara lo muestre.

El motivo de los cuatreros reaparece en el desenlace, el desenmascaramiento de Lad. El bloque 28 (1:09:02-1:09:46) es breve: Montorio repite la música del bloque 4, mientras el falso cura se dirige a la cuadra y espía a Lad, para crear suspense. En la noche, cuando Jim descubre a Lad en las cuadras, y confirma sus sospechas, ambos hombres se enfrentan: los disparos marcan el inicio del bloque 31A (1:17:36-1:20:20). Este bloque de 2 minutos y 45 segundos, que acompaña la pelea a muerte entre Jim y Lad y el incendio de la cuadra, comienza con el motivo (b) de los cuatreros en los metales (poderoso); a continuación, Montorio hilvana unos temas libres, empáticos, potentes tutti con timbales, mientras los hombres se golpean entre los cascos de los caballos. Torrado destaca los relinchos, el ruido de las llamas, jadeos y puñetazos que se mezclan con una música con tresillos amenazantes, motivos sometidos a un tratamiento secuencial ascendente en registro a medida en que se incrementa la tensión (tópicos musicales de persecuciones y peleas), alcanzando el clímax sinfónico.

En Los cuatreros también hay una cantidad respetable de música diegética o intradiegética para ambientar el Saloon: varios fox vaqueros, con frecuencia instrumentados para piano y banjo, en ocasiones con violín añadido (bloque 2, bloque 5, un slow en el bloque 5A, bloque 15 con acordeón y armónica, bloque 21 , bloque 30 con acordeón). Es interesante el bloque 5A (Lad está endeudado y pide más dinero a Taylor), en una secuencia donde se juega con varios puntos de escucha y la música (intradiegética) tiene una función estructural para unir planos y hacer avanzar la acción. En el film hay otros temas circunstanciales, sobre todo en el nudo de la acción: un motivo marcial en clarinetes y trompetas en sordina para caracterizar al ejército americano cuando llega el carro militar a la cárcel para escoltar a los presos (bloque 19: 46:15-46:35), música a gran orquesta para ilustrar persecuciones a caballo por la pradera (bloque 25: 57:20-58:38), por el desfiladero (bloque 25 A 58:39-59:10), y pelea cuerpo a cuerpo entre Jim y un cuatrero al que mata (bloque 25 B 59:10-1:00:58).

Los bloques $25,25 \mathrm{~A}$ y $25 \mathrm{~B}$ se escuchan sin solución de continuidad: son impactantes, tienen una función dramática y Montorio explota el potencial de la orquesta, con algunos tópicos musicales presentes en las entradas
Galloping y Hurry de las cue sheets del cine mudo (sincopaciones, ostinatos, repeticiones de motivos sometidos a un tratamiento secuencial acumulativo ascendente, trémolos), que incrementan la tensión de las imágenes, sin renunciar al dramatismo del ruido de los cascos de los caballos y los disparos, también en un primer plano sonoro al igual que los golpes y gritos de los dos hombres.

En la secuencia final, un último bloque 32 (1:20:571:21:34) resuelve el conflicto sentimental de la pareja. Comienza con un plano de Mary que baja corriendo las escaleras para encontrarse con Jim. Montorio acude al tema de Jim, que repite épico, triunfante, en los metales, mientras se abrazan, hablan de boda (plano medio) y se besan (primer plano). Por fin se desvela la verdadera identidad de Jim: un héroe, teniente del ejército. De este modo, la música de la película finaliza como el final de la música de cabecera, con el tema del héroe en plenitud.

\section{CONCLUSIONES}

El análisis de estos filmes confirma que Daniel Montorio, como otros compositores de cine del franquismo, estaba familiarizado con los códigos, tópicos y gestos musicales del cine americano "de género", en este caso el wéstern. La música está al servicio de la definición del género cinematográfico y subordinada a las imágenes, diálogos y tramas narrativas. Montorio pone en funcionamiento recursos desarrollados en el wéstern americano, más influido por la línea Aaron Copland y Jerome Moross que por las bandas sonoras de Max Steiner, Víctor Young o Dimitri Tiomkin. En líneas generales, la música de Montorio en estas películas es más proclive a las funciones dramática, perceptiva (temporal y espacial) y cognitiva que a la función emotiva, de tal forma que acompaña la narración, clarifica las narrativas y, por lo general, subraya más la acción que las emociones.

Montorio utiliza puntualmente el tópico pastoral (en los títulos de crédito de Los cuatreros), la técnica del leitmotiv, algunos tópicos musicales que conocía bien desde su etapa de pianista en locales de exhibición de cine en los años veinte (persecución, pelea, cabalgadas), anáfonas cinéticas y sinécdoques de lugar instrumentadas con banjo, violín y piano (músicas de ragtime, fox vaqueros, fox-trot, slow). Los bloques musicales para orquesta grande se reservan para los títulos de crédito, secuencias rodadas en exteriores o bien aquellas en las que intervienen los villanos, donde el compositor explota los timbres orquestales con un especial cuidado en el tratamiento del clarinete bajo y los metales, con detalles semióticos refinados y mostrando en ellos mayor osadía armónica. 
El compositor diseña algunos leitmotivs para fortalecer la unidad estructural del texto audiovisual y la coherencia con los mitos del género, sobre todo en Los cuatreros, donde los personajes son más estereotipados. La música de Los cuatreros colabora en la construcción de la agenda del héroe: los temas fundamentales refuerzan la bipolaridad del bien y del mal, destaca el contraste entre los temas de la pareja frente a los motivos de los cuatreros, reproduciendo el modelo ensayado en las bandas sonoras americanas de los años cincuenta para simbolizar los códigos del Manifest Destiny. Asimismo, en la música extradiegética de Los cuatreros se observa una fidelidad mayor a los tópicos musicales de género, siguiendo los convencionalismos de sesgo partiarcal que ponen en juego un conjunto de "identificaciones asimilantes" como era habitual en el wéstern americano.

Relevo para un pistolero presenta unos personajes más reales, humanizados y complejos, y una banda sonora más variada y sutil, donde abundan los temas circunstanciales. La influencia de Jerome Moross quizá pueda explicar la renuncia de Montorio a adjudicar temas a Relámpago y a Edwin Jackson, ya que en el clásico The Big Country (1958) tampoco hay temas específicos para los protagonistas, sino bloques musicales relacionados con aspectos narrativos o situaciones (novatada, ataque, emboscada, muerte de algún personaje) reiterados a lo largo de la película y que, a su vez, obedecen a la influencia de la música de cine de Copland ${ }^{65}$ No olvidemos que Copland está considerado el primer compositor de cine americano que rompió con las sonoridades post-románticas (Puccini, Strauss) y las técnicas poswagnerianas europeas (rechazando el uso del leitmotiv) sólidamente implantadas en los estudios de Hollywood. ${ }^{66}$ Así, en Relevo hay temas musicales asociados a elementos como la tienda o el pueblo de Blackstone, o a situaciones de tensión narrativa, con gestos y recursos musicales parecidos a los de Moross, explotando los timbres orquestales.

En Relevo para un pistolero destacan las canciones populares diegéticas interpretadas por mujeres, confirmándose la influencia de la revista teatral de los años sesenta, también presente en Los cuatreros a través del número de Katherine. Este aparente desfase entre la época en que se desarrollan las tramas dramáticas y la sonoridad de las canciones diegéticas no resulta problemático, lo importante es la connotación de sonidos "marginales" frente a las "virtudes" de la civilización: ${ }^{67}$ el Saloon es un

65 Whitmer, "Reinventing the Western film score", p. 64.

${ }^{66}$ Lerner, "Copland's music of wide open spaces", p. 496.

67 Scheurer, Music and mythmaking in film, p. 153. El autor lugar "marginal" donde cabe la violencia. La costumbre de introducir canciones cuya letra hacía referencia a la trama del film estaba asentada en el wéstern americano desde los años cincuenta; era habitual en las películas con música de Dimitri Tiomkin y se mantiene en el spaguetti-western de los años sesenta.$^{68}$ Cuando se trataba de cowboy songs, como en Río Bravo, articulaban nociones de masculinidad y conectaban los espacios del hotel, la cárcel y el Saloon, siendo fundamentales para la trama. ${ }^{69}$ Esto no ocurre en los filmes de Torrado, donde las canciones de Montorio no tienen función narrativa, ni funcionan como voz en off, y los cantables de las canciones de Katherine, Ann o Carmen no están relacionados con la trama ni con los protagonistas. Tampoco puede decirse que contribuyan a caracterizar a los personajes o que tengan un papel relevante en la carga ideológica del film, salvo en todo caso la ranchera de Carmen la mexicana. No obstante, las canciones de estas películas articulan una idea de feminidad concebida en términos patriarcales, ligada a unas estrategias de seducción que pueden suponer una amenaza para los hombres, sobre todo en Relevo para un pistolero. Por otro lado, podrían ser una concesión a los gustos del público español siguiendo la tradición del cine popular y comercial del franquismo de interpolar canciones en films que no pertenecen al género del musical.

El estudio de estas películas confirma que Daniel Montorio dominaba el medio cinematográfico y sabía sacar partido a los recursos que tenía a su disposición —a veces limitados - para construir eficaces bandas sonoras en películas hechas en serie, con evidentes intereses comerciales. Relevo para un pistolero y Los cuatreros son dos exclentes ejemplos de un wéstern hispano anterior al cambio de paradigmas narrativos y visuales que se impusieron tras los filmes de Leone y Morricone, gracias a dos profesionales veteranos de la dirección y composición que dominaban el oficio.

señala que esto es algo habitual en el wéstern americano donde hay músicas metateatrales con canciones al estilo de las baladas de Tin Pan Alley.

${ }^{68}$ Ocurre, por ejemplo, en películas posteriores como $\mathrm{La}$ balada de Johnny Ringo (José Luis Madrid, 1965), una coproducción hispanoalemana con música de Federico Martínez Tudó, o en la italiana Una pistola para Ringo (Duccio Tessari, 1965) con música de Morricone. Véase Ángel Justo Estebaranz y Lucía Pérez García, "Influencias de la música para wéstern de Dimitri Tiomkin en el Spaguetti Western", Ucoarte. Revista de Teoria e Historia del Arte, 4 (2015), pp. 93-113, 102.

${ }^{69}$ David L. G. Arnold, "My rifle, my pony and feathers: music and the making of men in Howard Hawk's Río Bravo", Quarterly Review of Film and Video, 23/3 (2006), pp. 267-279. 


\section{APÉNDICES}

\section{APÉNDICE 1. Entradas musicales (cue list) de Relevo para un pistolero.}

\begin{tabular}{|c|c|c|c|c|}
\hline Minutaje & Bloques & Fuente & Eventos musicales & Acción y diálogo \\
\hline $0-3: 04$ & & & Sin música & $\begin{array}{l}\text { Prólogo. Atraco y crimen de } \\
\text { Relámpago Harris. }\end{array}$ \\
\hline $3: 04-5: 15$ & 1 & Extradiegética & $\begin{array}{l}\text { Música de cabecera } \\
\text { (orquesta grande) }\end{array}$ & $\begin{array}{l}\text { Títulos de crédito. Una diligencia } \\
\text { atraviesa las llanuras del Far West }\end{array}$ \\
\hline $13: 07-15: 56$ & 2 & $\begin{array}{c}\text { Extradiegética y } \\
\text { underscoring }\end{array}$ & $\begin{array}{c}\text { Tema de la tienda } \\
\text { Tema de las chicas del Saloon } \\
\text { (violines, piano, banjo) }\end{array}$ & $\begin{array}{l}\text { Edwin atiende la tienda. Ann coquetea } \\
\text { con él. Las chicas se ríen porque no va } \\
\text { al Saloon }\end{array}$ \\
\hline $16: 03-16: 22$ & 3 & Extradiegética & $\begin{array}{c}\text { Tema circunstancial } \\
\text { (orquesta) }\end{array}$ & $\begin{array}{l}\text { Un jinete cabalga por la pradera: } \\
\text { Edwin va a visitar a Relámpago } \\
\end{array}$ \\
\hline 17:34-18:05 & 4 & Intradiegética & $\begin{array}{c}\text { Ragtime } \\
\text { (piano solo) }\end{array}$ & $\begin{array}{c}\text { La corista intenta convencer a Edwin } \\
\text { para que entre al Saloon }\end{array}$ \\
\hline $18: 06-22: 33$ & & $\begin{array}{c}\text { Diegética } \\
\text { (diégesis fluida, } \\
\text { transdiegética) }\end{array}$ & $\begin{array}{l}\text { Cuando estoy lejos de ti } \\
\text { (Trío de Payadores) }\end{array}$ & $\begin{array}{l}\text { En El Pulque, Edwin propone a Raúl } \\
\text { abrir una tienda para los mexicanos y } \\
\text { conoce a Carmen }\end{array}$ \\
\hline $22: 53-25: 20$ & 5 & $\begin{array}{l}\text { Extradiegética } \\
\text { (underscoring) }\end{array}$ & $\begin{array}{c}\text { Tema de Blacktown } \\
\text { (fox para banjo, luego } \\
\text { orquesta) }\end{array}$ & $\begin{array}{l}\text { Inauguración de la nueva tienda, La } \\
\text { Flor de México. Edwin y Relámpago } \\
\text { pasean por la calle y conversan }\end{array}$ \\
\hline $26: 42-28: 31$ & & Diegética & $\begin{array}{l}\text { Tequila, limón y sal } \\
\text { (voz y guitarra) }\end{array}$ & $\begin{array}{l}\text { Edwin se emborracha con tequila en } \\
\text { el Pulque y se marcha }\end{array}$ \\
\hline 29:46-31:09 & & $\begin{array}{l}\text { Diegética e } \\
\text { intradiegética }\end{array}$ & Número de baile & $\begin{array}{l}\text { Edwin entra al Saloon donde bailan } \\
\text { las coristas, y bebe en la barra }\end{array}$ \\
\hline \multirow[t]{2}{*}{$32: 04-34: 24$} & & $\begin{array}{c}\text { Diegética } \\
\text { (source scoring) }\end{array}$ & $\begin{array}{c}\text { Tú serás } \\
\text { (slow de Ann) }\end{array}$ & $\begin{array}{l}\text { Ann interpela a Edwin con su canción } \\
\text { tratando de seducirle }\end{array}$ \\
\hline & 6 & & Tema de Carmen & Fue suprimido \\
\hline $45: 20-47: 13$ & 7 & Extradiegética & $\begin{array}{c}\text { Temas circunstanciales } \\
\text { (motivos vinculados a la } \\
\text { banda de Dylon) (gran } \\
\text { orquesta) }\end{array}$ & $\begin{array}{l}\text { La banda de Dylon mata a Raúl, } \\
\text { registran El Pulque y Carmen huye. }\end{array}$ \\
\hline $47: 13-47: 31$ & $7 \mathrm{~A}$ & $\begin{array}{l}\text { Extradiegética } \\
\text { (underscoring) }\end{array}$ & $\begin{array}{l}\text { Tema circunstancial } \\
\text { (gran orquesta) }\end{array}$ & $\begin{array}{l}\text { Ann consuela a Carmen que está } \\
\text { aterrorizada. Huyen al rancho de } \\
\text { Relámpago donde está Edwin. La } \\
\text { banda de Dylon registra las tiendas }\end{array}$ \\
\hline $47: 32-48: 46$ & 8 & Extradiegética & $\begin{array}{l}\text { Tema circunstancial } \\
\text { (gran orquesta) }\end{array}$ & $\begin{array}{l}\text { La banda de Dylon destroza y prende } \\
\text { fuego a Jackson Store }\end{array}$ \\
\hline $54: 57-56: 08$ & & Diegética & $\begin{array}{l}\text { Dígame usted } \\
\text { (cuplé “cursi”) }\end{array}$ & $\begin{array}{l}\text { La canción de Ann se interrumpe } \\
\text { bruscamente cuando Edwin desafía a } \\
\text { Dylon }\end{array}$ \\
\hline $57: 58-58-07$ & 9 & Extradiegética & $\begin{array}{l}\text { Tema circunstancial } \\
\text { (orquesta) }\end{array}$ & $\begin{array}{c}\text { Tras la muerte de Dylon, un jinete } \\
\text { cabalga en la noche }\end{array}$ \\
\hline $58: 35-58-58$ & 10 & Extradiegética & $\begin{array}{l}\text { Tema circunstancial } \\
\text { (orquesta) }\end{array}$ & Deciden vengarse y asesinar a Edwin \\
\hline 58:59-1:00: 31 & 11 & $\begin{array}{l}\text { Extradiegética y } \\
\text { underscoring }\end{array}$ & $\begin{array}{c}\text { Tema de la tienda } \\
\text { (variaciones) y tema de } \\
\text { Blacktown } \\
\text { (orquesta pequeña) } \\
\end{array}$ & $\begin{array}{c}\text { En la tienda destrozada, Edwin está } \\
\text { desolado y Relámpago le propone } \\
\text { hacerse sheriff }\end{array}$ \\
\hline
\end{tabular}




\begin{tabular}{|c|c|c|c|c|}
\hline Minutaje & Bloques & Fuente & Eventos musicales & Acción y diálogo \\
\hline 1:02:17-1:04:19 & 12 & Extradiegética & $\begin{array}{l}\text { Tema libre. Variaciones de los } \\
\text { motivos de la banda de Dylon } \\
\text { (gran orquesta) }\end{array}$ & $\begin{array}{l}\text { Edwin y el sheriff se enfrentan a la } \\
\text { banda de Dylon, el sheriff muere. } \\
\text { Fundido a negro }\end{array}$ \\
\hline 1:05:28-1:07:00 & 13 & $\begin{array}{l}\text { Extradiegética } \\
\text { (underscoring) }\end{array}$ & $\begin{array}{c}\text { Tema de Carmen } \\
\text { ("amoroso", orquesta } \\
\text { pequeña) }\end{array}$ & $\begin{array}{c}\text { En La Flor de México, Edwin se } \\
\text { insinúa a Carmen. Ella le rechaza y se } \\
\text { va de la tienda con su novio }\end{array}$ \\
\hline 1:07:04-1:09:03 & 14 & Intradiegética & $\begin{array}{c}\text { Ragtime } \\
\text { (violín, piano y banjo) }\end{array}$ & $\begin{array}{l}\text { Edwin y el dueño juegan al póker en } \\
\text { el Saloon }\end{array}$ \\
\hline 1:09:32-1:10: 49 & $14 \mathrm{~A}$ & Intradiegética & $\begin{array}{c}\text { Slow (piano, batería, } \\
\text { contrabajo y banjo) y cabeza } \\
\text { del tema de Blacktown }\end{array}$ & $\begin{array}{l}\text { En el Saloon, Relámpago y Edwin } \\
\text { discuten, el joven ha cambiado }\end{array}$ \\
\hline $1: 12: 54-1: 13: 28$ & 15 & Extradiegética & $\begin{array}{c}\text { Tema de Carmen y variación } \\
\text { ("triste") } \\
\text { (piano, violín, banjo y } \\
\text { contrabajo) }\end{array}$ & $\begin{array}{l}\text { Tras ser rechazado por Carmen, } \\
\text { Edwin pasea por la calle, } \\
\text { malhumorado, de noche }\end{array}$ \\
\hline $1: 13: 44-1: 15: 16$ & & Diegética & $\begin{array}{c}\text { Número de baile } \\
\text { (fox-trot para piano, banjo y } \\
\text { violín) }\end{array}$ & $\begin{array}{l}\text { En el Saloon, Ann recrimina a Edwin } \\
\text { su actitud y que beba tanto. Edwin } \\
\text { provoca al novio de Carmen (Miguel) }\end{array}$ \\
\hline \multirow[t]{2}{*}{$1: 16: 35-1: 17: 03$} & & Intradiegética & Continúa el número de baile & $\begin{array}{l}\text { Ann dice a Edwin que se ha } \\
\text { convertido en un nuevo Dylon }\end{array}$ \\
\hline & 16 & Suprimido & $\begin{array}{l}\text { Breve tema libre en violines y } \\
\text { clarinete }\end{array}$ & \\
\hline $1: 19: 10-1: 22: 47$ & 17 & $\begin{array}{c}\text { Extradiegética y } \\
\text { underscoring }\end{array}$ & $\begin{array}{c}\text { Temas libres, tema de } \\
\text { Carmen en clarinetes, y } \\
\text { motivos de la banda de Dylon } \\
\text { (gran orquesta) }\end{array}$ & $\begin{array}{c}\text { Edwin pasea borracho por la calle, } \\
\text { entra en la tienda y se pone violento } \\
\text { con Carmen, que huye y muere tras } \\
\text { recibir un golpe }\end{array}$ \\
\hline $1: 24: 02-1: 24: 17$ & 18 & Extradiegética & $\begin{array}{l}\text { Tema circunstancial usa parte } \\
\text { de la música del bloque } 17 \\
\text { (orquesta) }\end{array}$ & $\begin{array}{l}\text { Miguel va a buscar a Carmen y la } \\
\text { encuentra muerta }\end{array}$ \\
\hline $1: 25: 29-1: 26: 33$ & 19 & Extradiegética & $\begin{array}{l}\text { Tema circunstancial } \\
\text { (orquesta) }\end{array}$ & $\begin{array}{l}\text { Galopada de Relámpago. Miguel } \\
\text { desafía a Edwin y éste baja a la calle } \\
\text { dispuesto a matarlo }\end{array}$ \\
\hline $1: 28: 27-F I N$ & 20 & Extradiegética & $\begin{array}{c}\text { Tema libre (a gran orquesta), } \\
\text { con variación en aumentación } \\
\text { del tema principal de los } \\
\text { créditos } \\
\text { (gran orquesta) }\end{array}$ & $\begin{array}{l}\text { Ann se abraza al cadáver de Edwin. } \\
\text { Relámpago, tras matar a Edwin, arroja } \\
\text { los revólveres y se aleja por la calle }\end{array}$ \\
\hline
\end{tabular}


APÉNDICE 2. Entradas musicales (cue list) de los cuatreros.

\begin{tabular}{|c|c|c|c|c|}
\hline Minutaje & Bloques & Fuente & Eventos musicales & Acción y diálogo \\
\hline $0-2: 52$ & & & Prólogo sin música & $\begin{array}{l}\text { Autoridades del Estado advierten a } \\
\text { Thompson. Asesinato del capataz }\end{array}$ \\
\hline $2: 53-5: 06$ & 1 & Extradiegética & $\begin{array}{l}\text { Títulos de crédito } \\
\text { (gran orquesta) }\end{array}$ & Un jinete cabalga por la pradera \\
\hline 1 minuto & $1 \mathrm{~A}$ & Suprimido & Tema de Mary & Diálogo entre Lad y Mary \\
\hline $5: 16-6: 16$ & 2 & Intradiegética & $\begin{array}{l}\text { Fox vaquero } \\
\text { (piano solo) }\end{array}$ & Pelea de borrachos en el Saloon \\
\hline $6: 44-9: 04$ & 3 & $\begin{array}{l}\text { Extradiegética } \\
\text { e intradiegética }\end{array}$ & $\begin{array}{c}\text { Tema de Jim } \\
\text { (piano, banjo y violín) }\end{array}$ & $\begin{array}{l}\text { Jim llega al pueblo y entra en el } \\
\text { Saloon }\end{array}$ \\
\hline 11:02-12:02 & 4 & Extradiegética & $\begin{array}{l}\text { Tema circunstancial, incluye } \\
\text { motivos de los cuatreros } \\
\text { (gran orquesta) }\end{array}$ & $\begin{array}{l}\text { Unos vaqueros intentan secuestrar a } \\
\text { Thompsom y Jim le salva }\end{array}$ \\
\hline $14: 48-15: 24$ & 5 & Intradiegética & $\begin{array}{c}\text { Fox vaquero } \\
\text { se toma del bloque } 2 \\
\text { (piano, violín y banjo) }\end{array}$ & $\begin{array}{c}\text { Lad juega al pocker en el Saloon y } \\
\text { pierde }\end{array}$ \\
\hline $15: 25-16: 41$ & $\mathbf{5 A}$ & Intradiegética & $\begin{array}{l}\text { Slow (piano, violín y banjo) } \\
\text { modificando puntos de } \\
\text { escucha }\end{array}$ & $\begin{array}{l}\text { Lad pide dinero prestado al dueño del } \\
\text { local (Taylor). Jim llega al Saloon }\end{array}$ \\
\hline $16: 45-17: 51$ & 6 & Intradiegética & $\begin{array}{c}\text { Tema de Jim } \\
\text { (piano solo) }\end{array}$ & $\begin{array}{l}\text { Jim en el Saloon charla con Taylor } \\
\text { hasta que Lad inicia una pelea }\end{array}$ \\
\hline 1 'y $11 "$ & 7 & Suprimido & Orquesta grande & $\begin{array}{l}\text { Pelea en el Saloon. Jim desarma a Lad } \\
\text { e impide que mate a un hombre }\end{array}$ \\
\hline 1 'y $45^{\prime \prime}$ & 8 & Suprimido & Acordeón & $\begin{array}{c}\text { En la terraza del rancho de sobremesa } \\
\text { (Thompson, Mary y Jim) }\end{array}$ \\
\hline 1'y 24 "' & 9 & Suprimido & Orquesta grande & Los vaqueros faenan con el ganado \\
\hline $23: 31-24: 31$ & 10 & $\begin{array}{l}\text { Extradiegética } \\
\text { (underscoring) }\end{array}$ & $\begin{array}{c}\text { Tema de Mary } \\
\text { (orquesta pequeña) }\end{array}$ & Mary y Jim pasean juntos a caballo \\
\hline $24: 32-25: 58$ & $\mathbf{1 0 A}$ & $\begin{array}{l}\text { Extradiegética } \\
\text { (underscoring) }\end{array}$ & $\begin{array}{c}\text { Tema de Jim y de Mary } \\
\text { alternan } \\
\text { (orquesta pequeña) }\end{array}$ & Mary y Jim charlan a la orilla del río \\
\hline $13{ }^{\prime \prime}$ & 11 & Suprimido & & Jim coge unas flores \\
\hline $14 "$ & 12 & Suprimido & & Mary le arroja el ramo a la cara. \\
\hline $10 "$ & $12 \mathrm{~A}$ & Suprimido & & $\begin{array}{c}\text { Mary se va enfadada y Jim le da las } \\
\text { flores al caballo }\end{array}$ \\
\hline $30: 12-31: 21$ & 13 & & $\begin{array}{c}\text { Tema de Mary } \\
\text { (orquesta pequeña) }\end{array}$ & Mary y su padre charlan en su cuarto \\
\hline $31: 22-31: 36$ & 14 & $\begin{array}{l}\text { Metateatral } \\
\text { (breve número } \\
\text { circense) }\end{array}$ & Tempo de mazurca & Breve actuación de unos payasos \\
\hline $32: 35-34: 40$ & & $\begin{array}{c}\text { Canción } \\
\text { metateatral }\end{array}$ & $\begin{array}{c}\text { Mi cariño es oro } \\
\text { (fox vaquero) }\end{array}$ & $\begin{array}{l}\text { Jim y Lad contemplan el número de } \\
\text { Katherine }\end{array}$ \\
\hline $35: 34-36: 50$ & 15 & Intradiegética & $\begin{array}{l}\text { Fox vaquero (bloques } 2 \text { y } 5 \text { ) } \\
\text { para piano, banjo, violín y } \\
\text { armónica }\end{array}$ & $\begin{array}{l}\text { Lad y Katherine charlan. Él sospecha } \\
\text { que conoce a Jim }\end{array}$ \\
\hline
\end{tabular}




\begin{tabular}{|c|c|c|c|c|}
\hline Minutaje & Bloques & Fuente & Eventos musicales & Acción y diálogo \\
\hline $36: 51-38: 21$ & 16 & Extradiegética & $\begin{array}{l}\text { Motivos de los cuatreros } \\
\text { (variación) y tema de Jim } \\
\text { (orquesta) }\end{array}$ & $\begin{array}{c}\text { Los cuatreros intentan robar caballos } \\
\text { y golpean a Jim }\end{array}$ \\
\hline $38: 22-38: 55$ & 17 & $\begin{array}{l}\text { Extradiegética } \\
\text { (underscoring) }\end{array}$ & $\begin{array}{l}\text { Tema de Jim en el clarinete } \\
\text { (variaciones) }\end{array}$ & $\begin{array}{l}\text { Jim vuelve en sí y habla con sus } \\
\text { hombres }\end{array}$ \\
\hline $39: 49-40: 43$ & 18 & Extradiegética & $\begin{array}{l}\text { Variaciones delos motivos de } \\
\text { los cuatreros (gran orquesta) }\end{array}$ & $\begin{array}{l}\text { Lad roba el cuchillo de Jim y un } \\
\text { mexicano asesina a un hombre (fuera } \\
\text { de cámara) }\end{array}$ \\
\hline $46: 15-46: 35$ & 19 & Extradiegética & $\begin{array}{c}\text { Tema circunstancial marcial } \\
\text { (clarinetes y trompetas en } \\
\text { sordina) }\end{array}$ & $\begin{array}{l}\text { Un carro militar con la escolta recoge } \\
\text { a los presos }\end{array}$ \\
\hline $47: 40-48: 07$ & 19A & Extradiegética & $\begin{array}{c}\text { Tema circunstancial (tópico } \\
\text { militar) }\end{array}$ & $\begin{array}{c}\text { El carro circula por la pradera y se } \\
\text { detiene }\end{array}$ \\
\hline $49: 48-50: 42$ & 20 & Extradiegética & $\begin{array}{c}\text { Fanfarria metales, tema de } \\
\text { Jim (trompas, épico) y tópico } \\
\text { militar (trompetas) } \\
\text { (gran orquesta) }\end{array}$ & $\begin{array}{l}\text { Jim y Pancho cabalgan (panorámicas } \\
\text { paisaje del Oeste) }\end{array}$ \\
\hline \multirow[t]{2}{*}{$52: 13-52: 49$} & 21 & Intradiegética & $\begin{array}{c}\text { Fox vaquero } \\
\text { (piano, violín y banjo) }\end{array}$ & $\begin{array}{l}\text { Katherine, en su camerino, recibe un } \\
\text { mensaje }\end{array}$ \\
\hline & 22 & Suprimido & & $\begin{array}{l}\text { Katherine acude a una falsa cita con } \\
\text { Jim donde la detienen los cuatreros }\end{array}$ \\
\hline $55: 11-55: 35$ & 23 & Extradiegética & $\begin{array}{l}\text { Motivos de los cuatreros } \\
\text { (gran orquesta) }\end{array}$ & $\begin{array}{l}\text { Los cuatreros desenmascaran a Jim y } \\
\text { le golpean }\end{array}$ \\
\hline $5 "$ & 24 & Suprimido & Alborada & Amanece en la sierra \\
\hline $57: 20-58: 38$ & 25 & Extradiegética & $\begin{array}{l}\text { Tema circunstancial } \\
\text { (tópico de persecución) } \\
\text { (gran orquesta) }\end{array}$ & $\begin{array}{l}\text { Los cuatreros persiguen a Jim a } \\
\text { caballo }\end{array}$ \\
\hline $58: 39-59: 10$ & $25 \mathrm{~A}$ & $\begin{array}{l}\text { Extradiegética } \\
\text { (underscoring) }\end{array}$ & $\begin{array}{c}\text { Temas circunstanciales (gran } \\
\text { orquesta) }\end{array}$ & $\begin{array}{l}\text { Lad es informado de que Jim se dirige } \\
\text { al desfiladero de los buitres }\end{array}$ \\
\hline $59: 10-1: 00: 58$ & 25B & Extradiegética & $\begin{array}{c}\text { Tema circunstancial } \\
\text { (gran orquesta) }\end{array}$ & $\begin{array}{l}\text { Disparos en el desfiladero, matan al } \\
\text { caballo de Jim, pelea cuerpo a cuerpo } \\
\text { con un cuatrero al que mata }\end{array}$ \\
\hline 1:02:36-1:04:14 & 26 & $\begin{array}{l}\text { Extradiegética } \\
\text { (underscoring) }\end{array}$ & $\begin{array}{c}\text { Variaciones del tema de Jim } \\
\text { y del tema de Mary } \\
\text { (orquesta pequeña) }\end{array}$ & $\begin{array}{l}\text { Mary reza en el cementerio en la } \\
\text { tumba de Jim y llega su "hermano } \\
\text { gemelo" }\end{array}$ \\
\hline 1:07:20-1:09:01 & 27 & $\begin{array}{l}\text { Extradiegética } \\
\text { (underscoring) }\end{array}$ & $\begin{array}{c}\text { Tema de Mary (variaciones y } \\
\text { desarrollo) } \\
\text { (orquesta pequeña) }\end{array}$ & $\begin{array}{l}\text { Mary y el falso cura (Jim) regresan } \\
\text { en calesa y se sientan en la terraza del } \\
\text { rancho }\end{array}$ \\
\hline \multirow[t]{2}{*}{ 1:09:02-1:09:46 } & 28 & Extradiegética & $\begin{array}{c}\text { Motivo de los cuatreros en } \\
\text { clarinete bajo } \\
\text { (orquesta grande) }\end{array}$ & $\begin{array}{l}\text { Jim se acerca a las cuadras a espiar a } \\
\text { Lad y su capataz }\end{array}$ \\
\hline & 29 & Suprimido & $\begin{array}{l}\text { Tópico de galopada } \\
\text { (orquesta) }\end{array}$ & Un jinete llega a galope al pueblo \\
\hline $1: 11: 25-1: 13: 35$ & 30 & Intradiegética & $\begin{array}{l}\text { Música de acordeón y banjo, } \\
\text { juega con puntos de escucha }\end{array}$ & $\begin{array}{l}\text { El falso cura llega al Saloon en busca } \\
\text { del sheriff y Taylor, Ladd recupera su } \\
\text { dinero y asesina a Taylor }\end{array}$ \\
\hline
\end{tabular}




\begin{tabular}{|c|c|c|c|c|}
\hline Minutaje & Bloques & Fuente & Eventos musicales & Acción y diálogo \\
\hline $1: 16: 50-1: 17: 29$ & $\mathbf{3 1}$ & Extradiegética & $\begin{array}{c}\text { Tema circunstancial, incluye } \\
\text { alusión al motivo de los } \\
\text { cuatreros en la flauta, golpe } \\
\text { musical } \\
\text { (gran orquesta) }\end{array}$ & $\begin{array}{c}\text { Lad va a las cuadras a comprobar si } \\
\text { a su caballo le falta una herradura, } \\
\text { es sorprendido por Jim y comienzan } \\
\text { disparos }\end{array}$ \\
\hline $1: 17: 36-1: 20: 20$ & $\mathbf{3 1 A}$ & Extradiegética & $\begin{array}{c}\text { Temas libres, } \\
\text { motivo de los cuatreros y } \\
\text { tópico de pelea } \\
\text { (orquesta grande) }\end{array}$ & $\begin{array}{c}\text { Pelea entre Jim y Lad en la cuadra } \\
\text { mientras se incendia. Fundido a negro }\end{array}$ \\
\hline $\begin{array}{c}\text { 1:20:57-1:21:34 } \\
\text { FIN }\end{array}$ & $\mathbf{3 2}$ & $\begin{array}{c}\text { Extradiegética } \\
\text { (underscoring) }\end{array}$ & $\begin{array}{c}\text { Tema de Jim repetido en los } \\
\text { metales, épico } \\
\text { (gran orquesta) }\end{array}$ & $\begin{array}{c}\text { Mary baja corriendo las escaleras, Jim } \\
\text { la espera con unas flores, se besan. } \\
\text { FIN }\end{array}$ \\
\hline
\end{tabular}

\section{BIBLIOGRAFÍA CITADA}

Aguilar, Carlos. "Entre zorros y coyotes: la extraña raíz del wéstern hispano-italiano de los años 60". Los límites de la frontera: la coproducción en el cine español. Cuadernos de la Academia, 5 (1999), pp. 29-41.

Alonso, Celsa. "Daniel Montorio y Eduardo G. Maroto: Los cuatro robinsones (1939), del juguete astracanesco al cine musical". Revista de Musicología, 41/1 (2018), pp. 199-233.

Arnold, David L. G. "My rifle, my pony and feathers: music and the making of men in Howard Hawk's Río Bravo". Quarterly Review of Film and Video, 23/3 (2006), pp. 267-279.

Audissino, Emilio. Film/Music analysis. A film studies approach. Cham: Palgrave Macmillan, 2017.

Barreiro, Javier. Maestro Montorio. Medio siglo de música popular española. Madrid: LCD Prames, 2004.

Beckerman, Michael y William H. Rosar. "The idyllic sublime: a dialog on the pastoral style in Westerns". The Journal of Film Music, 2/2-4 (2009), pp. 251262.

Bullerjahn, Claudia. Grundlagen der Wirkung von Filmmusik. Augsburg: Wißner, 2007.

Castro de Paz, José Luis y Jaime Pena Pérez. Ramón Torrado. Cine de consumo no franquismo. A Coruña: Centro Galego de Artes da Imaxe, 1993.

Castro de Paz, José Luis. "Ramón Torrado, un asalariado del cine bajo el régimen de Franco". En Actas del IV Congreso de la AEHC. Madrid: Editorial Complutense, 1993, pp. 289-298.

Estebaranz, Ángel Justo y Lucía Pérez García. "Influencias de la música para wéstern de Dimitri Tiomkin en el Spaguetti Western". Ucoarte. Revista de Teoría e Historia del Arte, 4 (2015), pp. 93-113.
Frayling, Christopher. Spaguetti-Westerns: cowboys and Europeans from Karl May to Sergio Leone. London: I. B. Tauris, 2006.

Gorbman, Claudia. Unheard melodies. Narrative film music. Bloomington, IN: Indiana University Press, 1987.

. "Scoring the indian: music in the liberal Western". En Western Music and Its Others: Difference, Representation and Appropiation in Music, editado por Georgina Born and David Hesmondhalgh. Berkeley, CA: University of California Press, 2000, pp. 234-253.

Grant, Kevin. Any gun can play. The essential guide to Euro-Westerns. Surrey: Fab Press, 2011.

Gutiérrez Recacha, Pedro. Spanish western: el cine del Oeste como subgénero español (1954-1965). Madrid: Ediciones de la Filmoteca, 2010.

Heldt, Guido. Music and leves of narration in film. Steps across the border. Bristol: Intellect, 2013.

Heredero, Carlos. Las huellas del tiempo. Cine español 1951-1961. Valencia: Filmoteca de la Generalitat Valenciana, 1993.

Huerta Floriano, Miguel Ángel. Los géneros cinematográficos. Usos en el cine español (1994-1999). Salamanca: Publicaciones Universidad Pontificia, 2005.

Kalinak, Kathryn. Settling the score. Music and the Classical Hollywood Film. Madison: University of Wisconsin Press, 1992.

. How the West was sung. Music in the westerns of John Ford. Berkeley, CA: University of California Press, 2007. , ed. Music in the Western. Notes from the frontier. New York: Rouledge, 2012.

Kassabian, Anahid. Hearing film. Tracking identifications in contemporary Hollywood film music. New YorK: Routledge, 2001. 
Leinberger, Charles. "The Dollars trilogy. "There are two kinds of western heroes, my friend!'”. En Music in the Western. Notes from the frontier, editado por Kathryn Kalinak. New York: Rouledge, 2012, pp. 131-147.

Leonard, Kendra Preston and Mariana Whitmer, eds. Relocating the sounds of the Western. New York: Routledge, 2019.

Lerner, Neil. "Copland's music of wide open spaces: surveing the pastoral trope in Hollywood". The Musical Quarterly, 85/3 (2001), pp. 477-511.

London, Justin. "Leitmotifs and Musical Reference in the Classical Film Score". En Music and cinema, editado por James Buhler, Caryl Flinn y David Neumeyer. Middletown, CT: Wesleyan University Press, 2000, pp. 85-96.

Miceli, Sergio. "Leone, Morricone and the Italian Way to revisionist Westerns". En The Cambridge companion to film music, editado por Marveyn Cooke y Fionna Ford. Cambridge: Camdridge University Press, 2016, pp. 265-294.

Neumeyer, David. Meaning and interpretation of music in cinema. Bloomington, IN: Indiana University Press, 2015.

Núñez Marqués, Anselmo. Wéstern a la europea.... Un plato que se sirve frío. Madrid: Entrelíneas Editores, 2006.

Padrol, Joan. "La música en las coproducciones con Italia". Los límites de la frontera: la coproducción en el cine español. Cuadernos de la Academia, 5 (1999), pp. 213-219.

Pisani, Michael. "'I'm and indian, too': creating native American identities in Nineteenth and Early Twentieth-Century Music". En The exotic in Western music, editado por Jonathan Bellman. Boston, MA: Northeastern University Press, 1998, pp. 218-257.

Rotellar, Manuel. Aragón en el CINE (IV). Zaragoza: Ayuntamiento de Zaragoza, 1973.

Scheurer, Timothy E. Music and mythmaking in film. Genre and the role of the composer. Jefferson, NC: McFarland \& Company, 2005.
Stanfield, Peter. Horse opera. The strange history of the 1930's singing cowboy. Chicago: University of Illinois Press, 2002.

Stilwell, Robynn J. "The Western". En The Cambridge companion to film music, editado por Marveyn Cooke y Fionna Ford. Cambridge: Camdridge University Press, 2016, pp. 216-230.

Stokes, Jordan Carmalt. "The Western as national epic. Musical persona and narrative distance in High Noon". En Music in epic film, editado por Stephen C. Meyer. New York: Routledge, 2017, pp. 210235.

Tagg, Philip y Bob Clarida. Ten little title tunes. Towards a musicology of the mass media. New York \& Montreal: The Mass Media Music Scholars’ Press, 2003.

Tagg, Philip. Music's meanings. A modern musicology for non-musos. New York \& Montreal: The Mass Media Music Scholars' Press, 2013.

Wennekes, Emile. "Out of tune? Jazz, Film and the Diegesis". En Cinema Changes: incorporations of jazz in the film soundtrack, editado por Emilio Audissino y Emile Wennekes. Turnhout: Brepols (2019), pp. 3-18.

Whitmer, Mariana. "Melodramatic music in the Western". Journal of Film Music, 5/1-2 (2012), pp. 109-119.

, "Reinventing the Western film score: Jerome Moross and The Big Country". En Music in the Western. Notes from the Frontier, editado por Kathryn Kalinak. New York: Routledge, 2012, pp. 5176.

Winters, Ben. "The nondiegetic fallacy: film, music and narrative space". Music and Letters, 91/2 (2010), pp. 224-244.

Zunzunegui, Santos. Los felices sesenta: aventuras y desventuras del cine español (1959-1971). Barcelona: Paidos, 2005.

Recibido: 31.12.2020

Aceptado: 21.06.2021 